\title{
Global biogeography of marine tintinnids
}

\author{
Richard W. Pierce*, Jefferson T. Turner \\ Biology Department, and Center for Marine Science and Technology, University of Massachusetts Dartmouth, \\ North Dartmouth, Massachusetts 02747, USA
}

\begin{abstract}
Literature records of tintinnid distributions (272 references, 1899 to 1992) were plotted with a computer. Distributions at the genus level revealed several distinct biogeographic patterns: cosmopolitan, neritic, warm-water, boreal, and austral. Some of the factors that may account for these patterns are examined. At the species level, certain disjunct distributions are examined, including the bipolar distribution of Acanthostomella norvegica and the interoceanic distributions of tropical tintinnids. Endemicism of species within certain genera, such as Codonellopsis, was also found.
\end{abstract}

\section{INTRODUCTION}

Tintinnids (Protozoa, Ciliata) have been known to marine biologists since the beginnings of plankton study (Haeckel 1873, Daday 1887), and records for tintinnid occurrences appear from all the oceans of the world (Pierce \& Turner 1992). Tintinnid biogeographic distributions in relation to hydrography are wellknown for certain areas including the North Atlantic (Campbell 1942, Gaarder 1946, Zeitzschel 1966, 1967 , Lindley 1975), South Atlantic (Balech 1971, Souto 1981), Pacific (Kofoid \& Campbell 1939, Campbell 1942, Balech 1962), Mediterraneran Sea (Jörgensen 1924, Balech 1959, Travers \& Travers 1971, Travers 1973), western Arabian Sea (Zeitzschel 1969, 1982), the coast of India (Krishnamurthy et al. 1979, Naidu \& Krishnamurthy 1985), the Adriatic Sea (Krsinic 1982, $1987 a, b, 1988$ ), the front between the Oyashio and Kuroshio Currents (Yamamoto et al. 1981, Taniguchi 1983) and the Southern Ocean (Laackmann 1907, 1909, Balech 1958a, b, 1971, 1973, Boltovskoy et al. 1989, Alder \& Boltovskoy 1991a, bj. Tintinnids as indicators of upwelling have also been investigated by Balech (1972). Nonetheless, a global synthesis of tintinnid biogeography has not emerged.

A major barrier to defining tintinnid biogeography is poor understanding of tintinnid taxonomy. This

\footnotetext{
- Present address and address for reprint requests: Graduate School of Oceanography, University of Rhode Island, Narragansett, Rhode Island 02882, USA
}

taxonomy is based upon morphology of the lorica, or shell. Because tintinnid loricae are relatively sturdy, preserve well and are captured in fine-meshed plankton nets, there are many records of tintinnid occurrences scattered throughout the literature. In addition to studies on tintinnids or microzooplankton, many such records come from collection in phytoplankton samples. Tintinnid loricae have also left a fossil record dating back to the Ordovician (Tappan \& Loeblich 1973). Unfortunately, from a taxonomic point of view, sizes and shapes of tintinnid loricae are highly variable within species. This variability has led to a proliferation of described species, many of which are probably not valid. Recent re-examinations of several tintinnid species and genera have resulted in suggestions to reduce many species to synonyms (Burkovskii 1973, Bakker \& Phaff 1976, Davis 1978, 1981, LavalPeuto 1981, 1983, Laval-Peuto \& Brownlee 1986, van der Spoel 1986, Boltovskoy et al. 1990). The protargol silver-staining technique, which allows comparisons of infraciliary patterns, is used with increasing frequency for tintinnid taxonomy (Brownlee 1977, Sniezek et al. 1991, Snyder \& Brownlee 1991, Choi et al. 1992).

Due to their hard loricae, tintinnids are the best known group of marine ciliates, but the durability of loricae can also cause problems. Collection with plankton nets has been found to cause tintinnids to abandon loricae (Paranjape \& Gold 1982), and preservation may also destroy the fragile ciliate cell, leaving the lorica unaffected. Empty loricae sink at rates of up to $1.5 \mathrm{~m} \mathrm{~d}^{-1}$ (Smayda \& Bienfang 1983), and 
loricae of estuarine tintinnids can be carried hundreds of kilometers offshore before settling to the sediments (Echols \& Fowler 1973). Thus, it is difficult to tell if empty loricae in samples were occupied at the time of collection, or were abandoned and transported to different areas by currents. For biogeographic studies, it is important to know where an organism lives. Once this has been established, the presence of empty loricae of alien species can be used as indicators of unusual water mass movements.

\section{METHODS}

Information on tintinnid distributions came from the 272 references listed in the Appendix. A data base was constructed using species name, and latitude and longitude of collection. When coordinates were not given, they were approximated based on either location names or maps included in the work. The resulting data base includes over 17000 records, from more than 1400 locations (Fig. 1).

This data base was then used to produce maps showing the reports of each tintinnid genus. Six distribution patterns emerged from these maps: cosmopolitan, warm-water, neritic, boreal, austral, and tropical Pacific. The criteria used in selecting these distributions are discussed under each distribution. Genera were then fit by eye and assigned to these categories. A few minor genera did not have enough data for assignment to any distributional category.

In order to use as much of the data as possible, only the presence of a tintinnid at a particular location was used. While this approach ignores much useful infor- mation in the form of water temperature, salinity, and depth of occurrence, it also allows for the inclusion of data that would otherwise be unusable. In addition to surveys and seasonal studies on tintinnids, information was also obtained from phytoplankton surveys and from larval fish and zooplankton feeding studies. Thus, although over 1400 locations have been included, many locations have only been sampled once, or did not identify all tintinnids which occur at that location.

Genus was used for plotting distributions for 3 reasons: it eliminates many taxonomic problems due to possible species misidentifications or synonomy; many of the approximately 900 described tintinnid species are represented by fewer than 15 recorded occurrences; and use of genus allows inclusion of data from phytoplankton surveys and larval fish feeding studies where only genus-level identification of tintinnids is common.

The use of genus also has limitations. Although taxonomic groups such as genus are ideally monophyletic, limitations in our knowledge often result in genera that are artificial (Balech 1975, Laval-Peuto 1981, 1983). Additionally, all members of a genus do not necessarily share the same biogeographic distribution. Thus, although a genus may have a cosmopolitan distribution due to many scattered species, no single species within the genus necessarily has a cosmopolitan distribution. Therefore, some species-level distributions have been included where appropriate.

\section{RESULTS AND DISCUSSION}

Table 1 assigns most of the extant tintinnid genera to a biogeographic distribution category. Specific examples from each type of distribution are given in Figs. 2 to 18 . We also discuss each type of distribution, and some of the physical and biological factors which may contribute to these distributions.

\section{Cosmopolitan distribution}

Both Kofoid (1915) and Campbell (1954) considered most species of tintinnids to have cosmopolitan distributions, believing that most exceptions were due to incomplete sampling. Fig. 1 shows the locations of all data points used in our survey. Although large areas of the world ocean have not yet been sampled for tintinnids, enough data exist to determine that most genera are not cosmopolitan. Here we define cosmopolitan as occurring in all oceans from the Arctic, through the tropics, and into the Ant-

Fig. 1. Locations of all occurrences used in this survey $(n>1400)$ 
Table 1. Biogeographic distribution of tintinnid genera

\begin{tabular}{|ll|}
\hline Cosmopolitan & Warm water \\
Acanthostomella & Amplectella \\
Amphorellopsis & Ascampbelliella \\
Amphorides & Brandtiella \\
Codonella & Canthariella \\
Codonellopsls & Climacocylis \\
Coxliella & Codonaria \\
Dictyocysta & Cyttarocylis \\
Epiplocylis & Dadayiella \\
Eutintinnus & Daturella \\
Ormosella & Epicancella \\
Parundella & Epicranella \\
Protorhabdonella & Epiplocyloides \\
Salpingacantha & Epiorella \\
Salpingella & Epirhabdonella \\
Steenstrupiella & Petalotricha \\
Undella & Poroecus \\
Neritic & Rhabdonella \\
Favella & Rhabdonellopsis \\
Helicostomella & Rhabdosella \\
Leprotintinnus & Stelidiella \\
Metacylis & Undellopsis \\
Stenosemella & Xystonella \\
Stylicauda & Xystonellopsis \\
Tintinnopsis & Tropical Pacific \\
Boreal & Amplectellopsis \\
Parafavella & Codonopsis \\
Ptychocylis & Cricundella \\
Austral & \\
Cymatocylis & \\
Laackmanniella & \\
& \\
& \\
& \\
& \\
& \\
& \\
& \\
& \\
&
\end{tabular}

arctic, with no restrictions as to distance from shore. Cosmopolitan species do not necessarily occur in high arctic or antarctic waters, but they must occur in cold waters near these areas. It would not be unexpected to find species from cosmopolitan genera in any sample from marine waters. Codonellopsis (Fig. 2) and Salpingella (Fig. 3) are examples of genera showing cosmopolitan distributions. A total of 16 genera including Coxliella share this type of distribution (Table 1).

The inclusion of the genus Coxliella is somewhat problematic, however, since it has been shown that $C$. annulata and $C$. decipiens are phenotypic variations of Favella eherenbergii (Laval-Peuto 1981, 1983). It is unknown if the remaining members of the genus are valid species or alternate phenotypes of existing species, but Corliss (1979) suggested replacing the family name Coxliellidae with the name Metacylididae as it is questionable if any valid Coxliella exist.

\section{Endemicism}

Although a genus may show a cosmopolitan distribution, this is not necessarily true for all the species within the genus. Fig. 4 shows the distributions of 3 species of Codonellopsis. C. lagenula is restricted to the North Atlantic and Mediterranean (Jörgensen 1924, Gaarder 1946, Lindley 1975), C. gaussi to the Southern Ocean (Laackmann 1907, 1909, Balech 1958a, b, 1971, 1973, Boltovskoy et al. 1989, Wasik \& Mikolajczyk 1990, Alder \& Boltovskoy 1991b), and $C$. ecaudata is found only in the tropical Pacific and Indian Oceans (Kofoid \& Campbell 1939, Campbell 1942, Balech 1962, Zeitzschel 1982). Note that these distributions are tentative, as the cellular morphology of none of these species is known.

Because of taxonomic problems, it is uncertain how many tintinnids are endemic, but as an example, there are 103 species of genus Tintinnopsis listed in our data base. Of these, 27 have only been reported once, and another 11 can also be considered endemics. While many of these species are no doubt synonyms, and our data base does not contain every record ever reported, this endemicism of species within widely distributed genera appears to be a common pattern for tintinnids.

\section{Neritic distribution}

Seven tintinnid genera have been found to be neritic, or restricted to relatively shallow waters. These include the genera Tintinnopsis (Fig. 5), Stenosemella

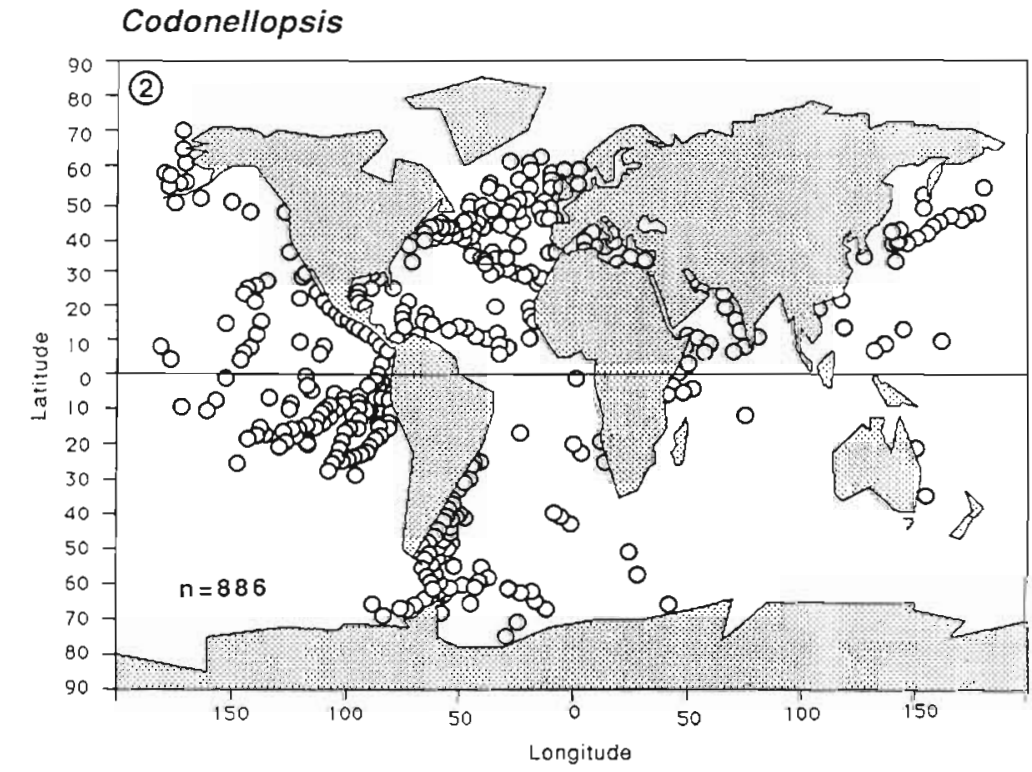

Fig. 2. Global distribution of the genus Codonellopsis 
Salpingella

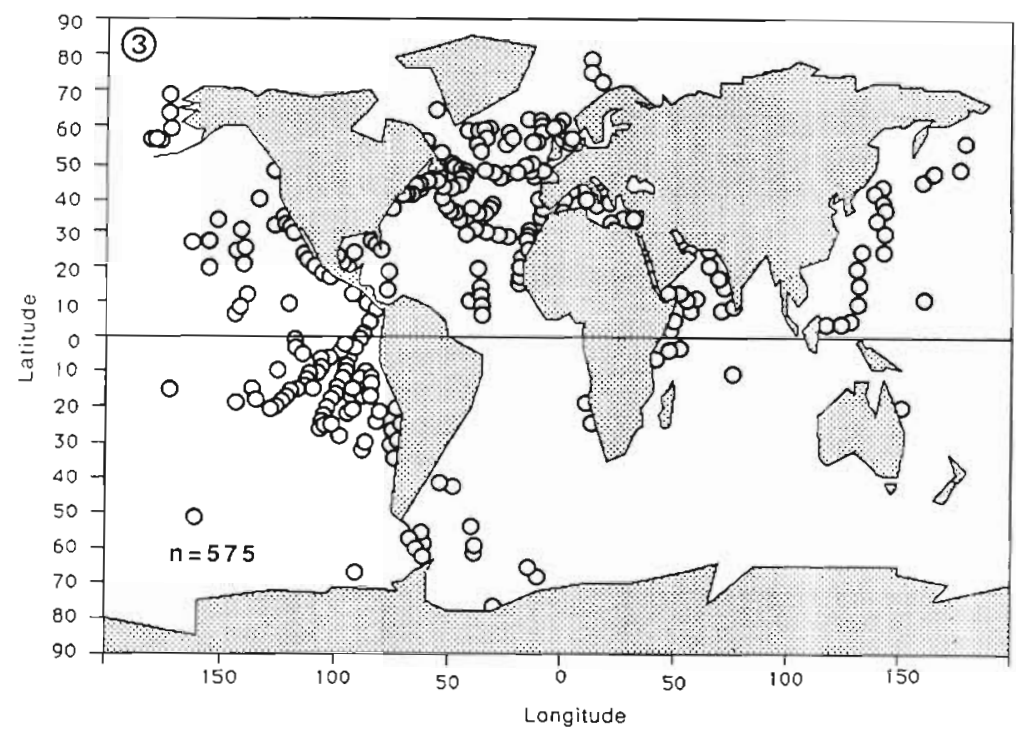

Fig. 3. Global distribution of the genus Salpingella

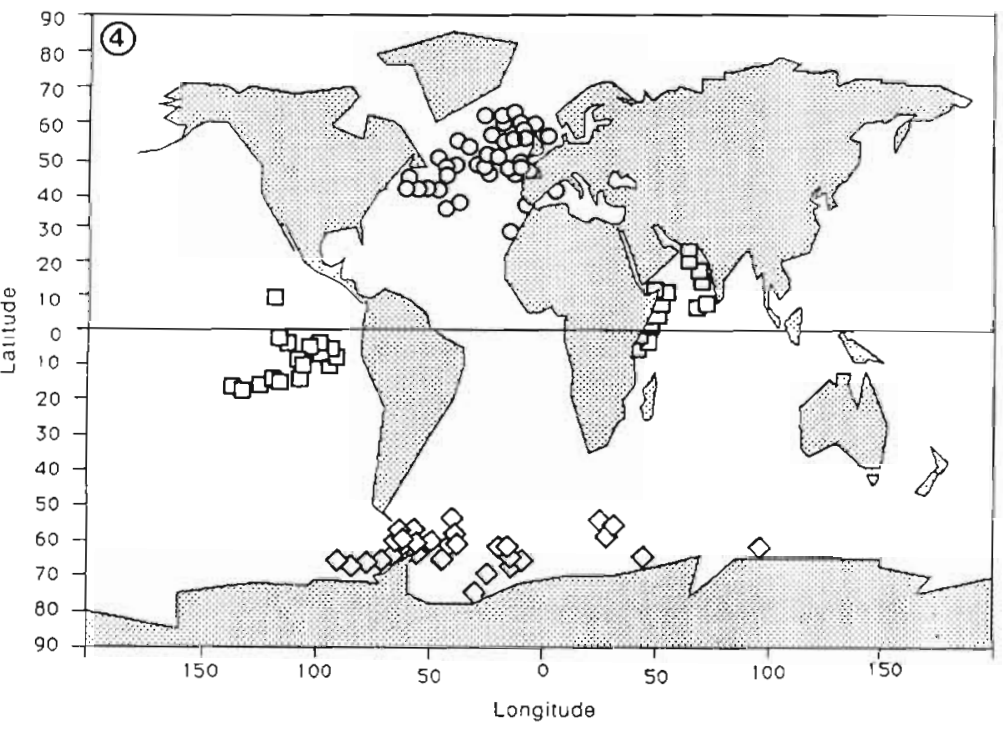

Fig. 4. Global distribution of Codonellopsis ecaudata, Codonellopsis gaussi, and Codonellopsis lagenula

Neritic genera exhibit several characteristics that may limit their distributions. Tintinnopsis, Stenosemella, Stylicauda, and Leprotintinnus are noted for the incorporation of mineral flakes into loricae. Although other genera contain species that incorporate particles into their loricae, all species within these four genera do so. When offshore species of other genera such as Codonella, Codonaria, Codonellopsis and Dictyocysta incorporate particles into the lorica, coccoliths are typically used (Gold \& Morales 1977, Takahashi \& Ling 1984). In culture, when deprived of suitable particles, Tintinnopsis produces a clear, but much weaker lorica (Gold \& Morales 1976). If mineral flakes are required to strengthen the loricae, tintinnids such as Tintinnopsis and Stenosemella may be restricted to shallow waters where these particles are readily available. Not all neritic tintinnids incorporate particles in loricae, however, as demonstrated by Favella and Helicostomella.

Another characteristic of neritic tintinnids is the production of resting cysts Cysts have been found in Tintinnopsis, Stenosemella, Leprotintinnus, Favella, and Helicostomella. Other genera known to produce resting cysts include: Acanthostomella, Amphorides, Cyttarocylis, Eutintinnus, Parafavella, Parundella, Rhabdonella, and Salpingella (Reid \& John 1978). Smayda (1958) noted that many neritic diatoms also produce resting cysts, although not all such species do so.

In shallow waters tintinnid cysts typically sink and are found in the sediments (Krsinic 1987a, Kamiyana \& Aizawa 1990). When appropriate conditions are provided, excystment and repopulation of the plankton occurs rapidly (Kamiyana \& Aizawa 1990, 1992). Darkness inhibits excystment, suggesting that most cysts must be mixed back into the water column before excystment can occur (Kamiyama \& Aizawa 1992). Cysts may be of little value for oceanic species, because once cysts

(Fig. 6), Helicostomella (Fig. 7) and Favella (not shown). These are the most familiar genera upon which all but a few of the laboratory experiments on feeding or other aspects of tintinnid ecology have been done. Although neritic tintinnids may be collected offshore, this usually occurs in a major ocean current that has previously traveled along the coast, or near islands. sink below the mixed layer, it is doubtful that they would ever be recruited back into the epipelagic population.

\section{Warm-water distribution}

The largest number of genera occur in tropical and temperate waters of the world's oceans (Table 1). 
Tintinnopsis

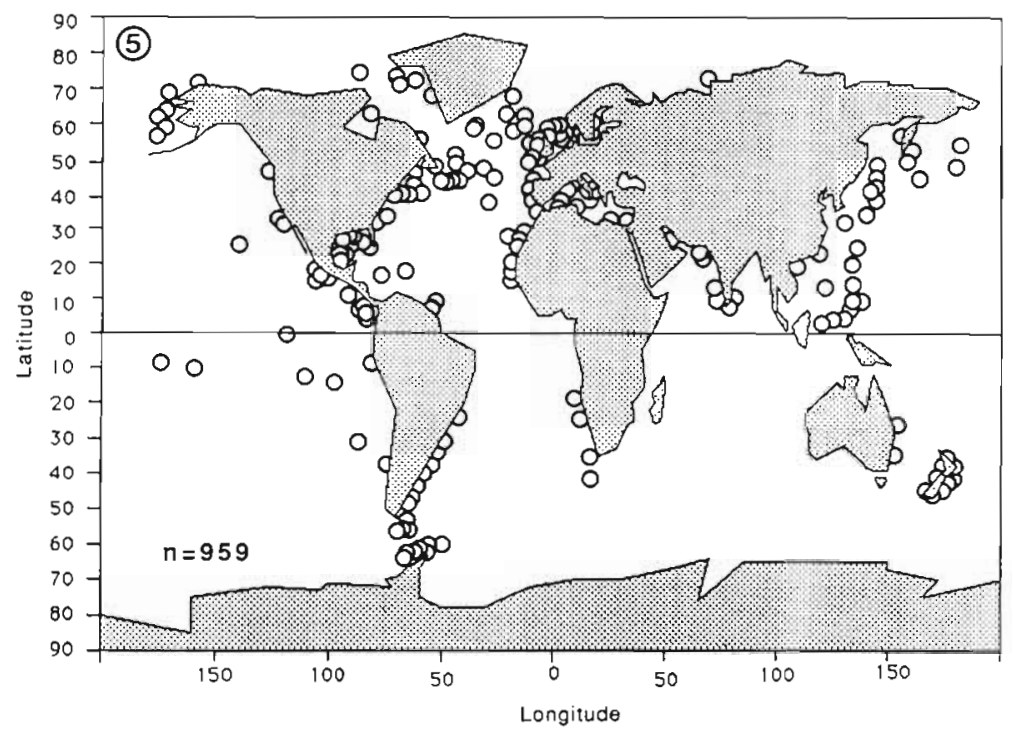

Fig. 5. Global distribution of the genus Tintinnopsis

Stenosemella

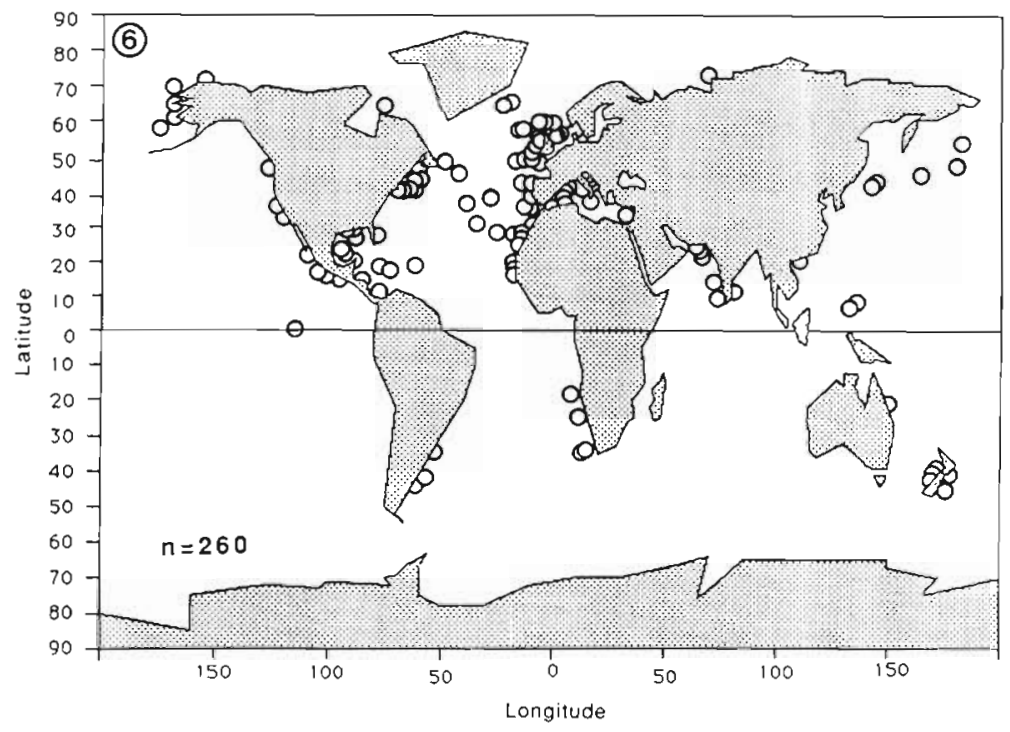

Fig. 6. Global distribution of the genus Stenosemella there is an enigma with the circumglobal warm-water distribution at the species level. The distributions of Petalotricha ampulla (Fig. 10) and Rhabdonellopsis apophysata (Fig. 11) are 2 examples of species with circumglobal warm-water distributions. Although it is unknown if the Atlantic and Pacific populations of these tintinnids are isolated, their distributions suggest that genetic interchange between these populations would be rare. It may be that these species attained circumglobal distributions before the emergence of the Central American Isthmus, and that their present distribution is a relict of previous times. Alternatively, Atlantic and Pacific populations of these and similarly distributed planktonic organisms may be analagous species (Shih 1986)

Analagous species are species that were once considered to be widely distributed, but show subtle differences which justify splitting a single taxon into multiple distinct species. Analagous species typically occupy similar latitudinal ranges in different oceans. Shih $(1979,1986)$ discussed how this applies to several calanoid copepods, most notably Calanus finmarchicus. Prior to 1948, C. finmarchicus was considered to be widely distributed throughout the northern hemisphere and around the southern portions of South America, Africa, Australia and New Guinea. Presently the $C$. finmarchicus species group has been split into 8 species, each with more restricted but sometimes overlapping distributions. Although there is evidence that some copepod morphology is the result of phenotypic variation due to environmental factors, Frost (1989) and Sevigny et al. (1989) showed that subtle morphological dif-

Although records of occurrence rather than water temperatures were criteria for assigning this distribution, 2 examples, Petalotricha (Fig. 8) and Rhabdonellopsis (Fig. 9), suggest that distributions of these genera in the North Atlantic are limited by the Gulf Stream. The poleward distribution of warm-water species is probably limited by seasons, and fluctuations in mean axes or meanderings of warm currents.

Although the distributions of genera may easily be explained by past connections between the oceans, ferences in the copepod genus Pseudocalanus are supported by biochemical evidence for these differences.

The determination of analagous species in tintinnids is complicated by the large amount of morphological variation of the loricae within a species (Burkovskii 1973, Bakker \& Phaff 1976, Davis 1978. 1981, Laval-Peuto 1981, 1983, Laval-Peuto \& Brownlee 1986, van der Spoel 1986, Boltovskoy et al. 1990). This requires the application of techniques to 
Helicostomella

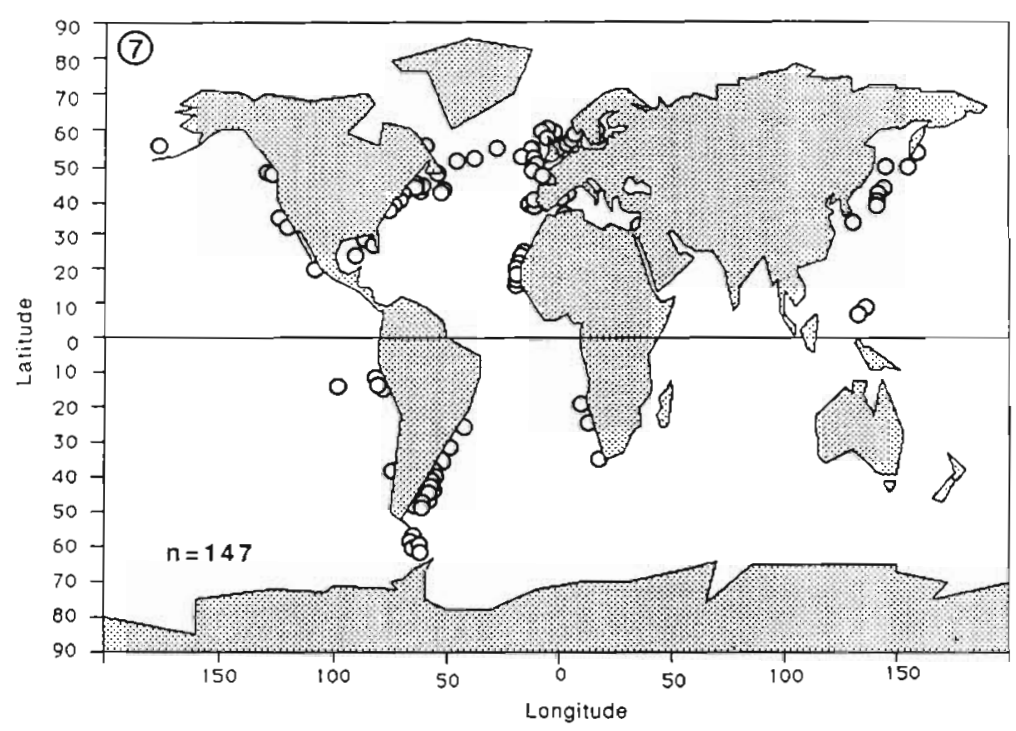

Fig. 7 Global distribution of the genus Helicostomella

Petalotricha

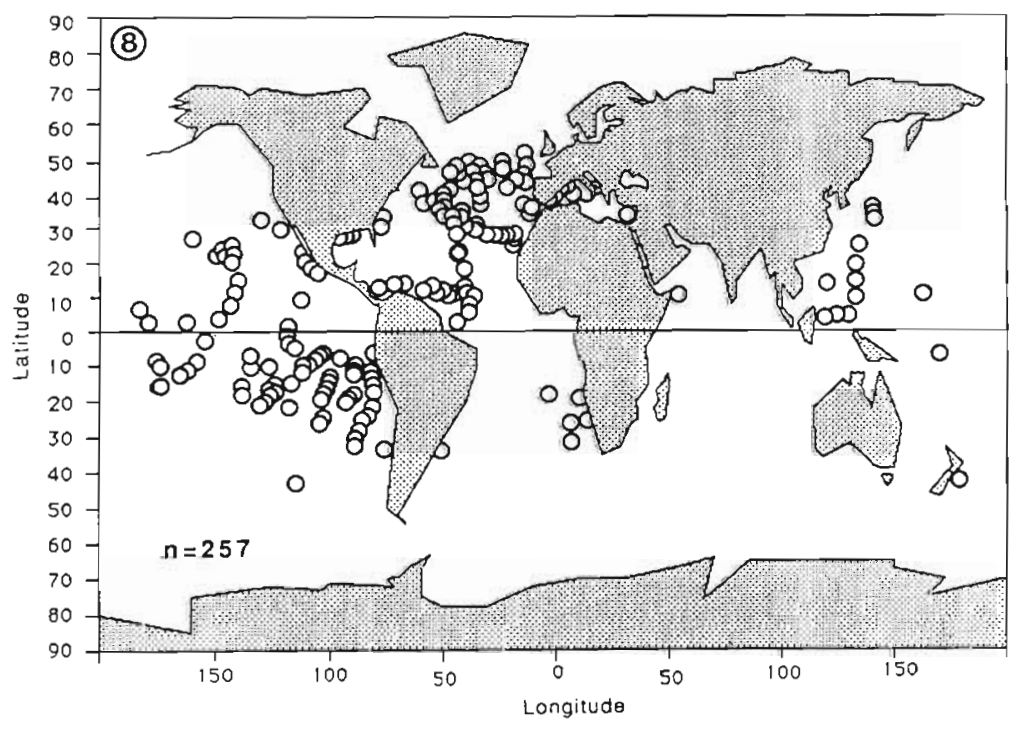

Fig. 8. Global distribution of the genus Petalotricha

examine the tintinnid cell. Unfortunately, neither genetic nor cell morphological differences between populations of any tintinnid species have been studied. Thus, the true nature of many tintinnid species distributions will likely remain enigmatic until such study is done.

A special subset of the warm-water distribution is found in three genera restricted to the tropical Pacific, namely Amplectellopsis (Fig. 12) and Codonopsis (not shown) and Cricundella (Fig. 13). These genera are somewhat problematic in that they are represented by only a few species, often based on few individuals, and records for these genera are rarely reported in the literature. These genera are closely allied with larger, more widely distributed genera, such as Amplectella (for Amplectellopsis), Codonella (for Codonopsis), and Undella (for Cricundella). Thus, many of the species within these 3 genera may be aberrant individuals of these larger genera.

\section{Boreal distribution}

Two genera, Parafavella (Fig. 14) and Ptychocylis (Fig. 15), have long been known to be restricted to cold waters in the Northern Hemisphere These tintinnids are not truly arctic as they are often found in subarctic waters (Kofoid \& Campbell 1929). Cape Hatteras is a well-known biogeographic boundry on the American east coast (Ekman 1953, Pielou 1979), and appears to be the southern limit of these tintinnids in the western Atlantic. Cape Hatteras is near the area where the Gulf Stream turns away from the the coast and is deflected eastward. Similarly, in the North Pacific, the Kuroshio Current acts as the southern boundary for these species. As with warm-water genera, records of occurrence rather than water temperatures were used in assigning boreal distributions. There is an area of overlap between the warm and cold-water distributions, which probably represents changes in tintinnid fauna due to seasonal temperature changes, or meandering of western boundary currents such as the Gulf Stream or the Kuroshio.

Species identifications within Parafavella and Ptychocylis are complicated by the fact that both of these genera have been found to show a large amount of lorica variation within a species (Burkovskii 1973, Davis 1978, 1981). It is uncertain how many of the 23 Parafavella species described by Kofoid \& Campbell (1929) are valid species. Burkovskii (1973) stated that there was so much variation and overlap of Parafavella specimens in the White Sea that only one species, Parafavella denticulata, was valid. Davis (1978) cautioned that this decision was premature, and that cell morphology must be studied before this determination can be made with confidence. 


\section{Rhabdonellopsis}

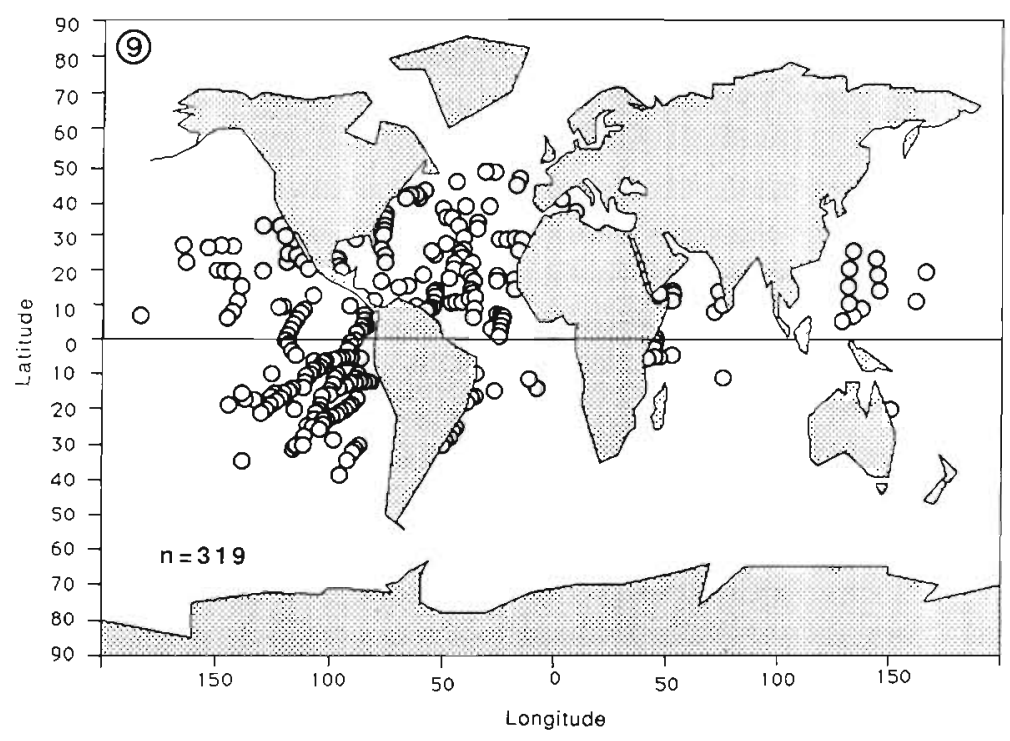

Fig. 9. Global distribution of the genus Rhabdonellopsis

Petalotricha ampulla

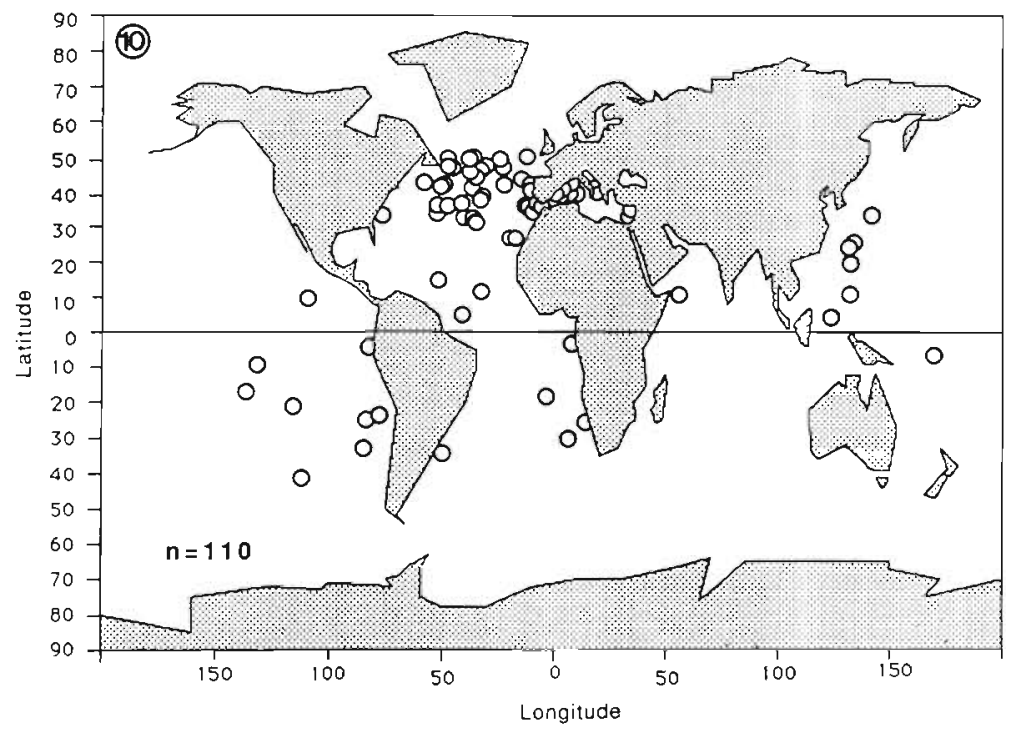

Fig. 10. Global distribution of Petalotricha ampulla

\section{Austral distribution}

Two genera, Cymatocylis (Fig. 16) and Laackmanniella (Fig. 17) are restricted to antarctic and subantarctic waters. Like its Northern Hemisphere counterparts Parafavella and Ptychocylis, Cymatocylis has been found to show considerable plasticity in lorica structure within a 'species' (van der Spoel 1986, Boltovsky et al. 1990).

The distributional maps of Cymatocylis, Parafavella. and Ptychocylis all contain records for anomalous species which should be viewed with skepticism, because they may represent misidentifications.

Northern Hemisphere records for Cymatocylis have only been reported by 2 authors, Silva (1953) and Lindley (1975). Silva (1953) reported a single specimen of $C$. subconica from the Lagoa de Obidos on the coast of Portugal. A brief discussion of the taxonomic history of Cymatocylis is relevant to understanding the confusion surrounding this genus.

When Kofoid \& Campbell (1929) revised the genus Cymatocylis, they had to rely mostly on drawings from Laackmann (1909), based on specimens from the 'Deutschen Südpolar-Expedition 1901-1903'. Laackmann had adopted a trinomial system of nomenclature, however, and for each taxon described a forma typica followed by numerous 'Formenkreise'. It appears that Laackmann tried to show the typical form of a species, along with variations which occurred. Current thinking regarding the amount of variation of lorica morphology within a species (Burkovskii 1973, Bakker \& Phaff 1976, Davis 1978, 1981, Laval-Peuto 1981, 1983, Laval-Peuto \& Brownlee 1986, van der Spoel 1986, Boltovskoy et al. 1990), suggests that most of these 'Formenkreise' were aberrant examples with no taxonomic standing of their own. Kofoid \& Campbell, however, in trying to adapt Laackmann's trinomial system to a binomial system, chose to raise each 'Formenkreis' to the level of species, cautioning that this was tentative pending re-examination of antarctic material. Unfortunately, Kofoid \& Campbell never returned to this genus, and their classification has stood since 1929. Many other genera and species also established by Kofoid \& Campbell require substantial revision. Of the 45 Cymatocylis species Kofoid \& Campbell (1929) described, only 19 have subsequently been reported in the literature examined for this study.

One of the species raised from the 'Formenkreis' level was Cymatocylis subconica (Kofoid \& Campbell 1929). This was based on 2 specimens Laackmann named as Cymatocylis cristalina forma conica and Cymatocylis flava forma conica. Silva's (1953) single specimen is the only subsequent report of this species since 1929 . 


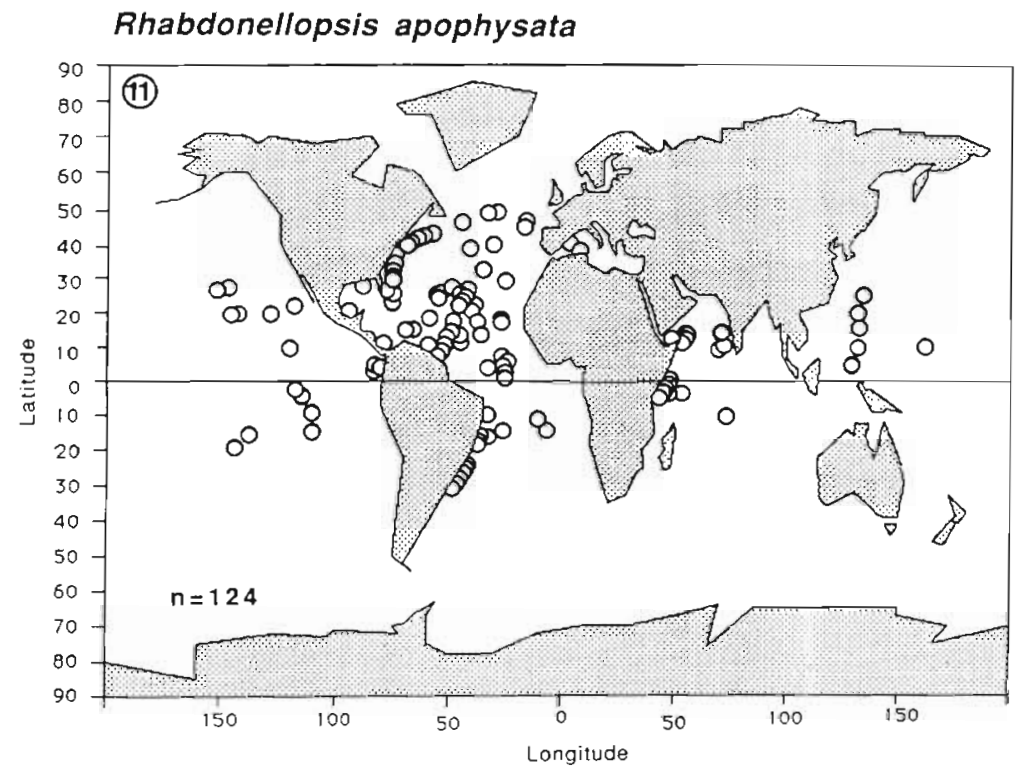

Fig. 11. Global distribution of Rhabdonellopsis apophysata

\section{Amplectellopsis}

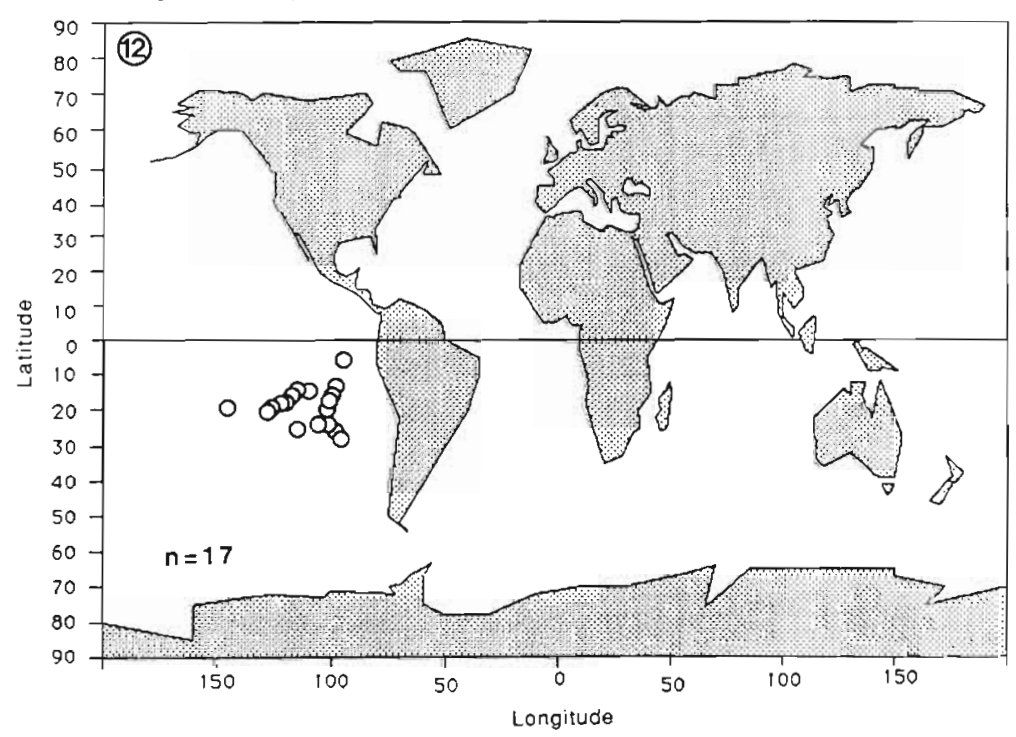

Fig. 12. Global distribution of the genus Amplectellopsis

coverslip will distort many tintinnid loricae such that measurements of the lorica oral diameter are useless for identification. With appropriate measures, such as the use of Sedgwick-Rafter chambers, this problem is avoided. Kofoid (1915) described how distortion of some Dictyocysta specimens may have been responsible for the description of a 'new species'. Thus, it is possible that distorted or aberrant specimens of the genus Ptychocylis could easily be mistaken for Cymatocylis. Lindley's records are also puzzling since the North Atlantic is one of the areas which has been well-surveyed for tintinnids, and no other Cymatocylis specimens have been reported. However, Lindley has confirmed that Cymatocylis has been found in subsequent continuous plankton recorder tows in the North Atlantic (pers. comm.).

Tumantseva (1989) reported 24 specimens of Parafavella brandti in the subantarctic Pacific, even though other species of this genus appear centered in boreal waters. $P$. brandti is a problematic species, first described by Hada (1932) for specimens which fit the description of Parafavella gigantea, but lacked the characteristic oral denticles. Davis (1978) noted that it was not unusual to find a certain number of loricae of Parafavella lacking the oral denticles in any given sample, and the presence, absence, or number of oral denticles was not a conservative taxonomic characteristic. However, none of Tumantseva's specimens had oral denticles, otherwise they would have been classified as $P$. gigantea. Species within the genera Xystonella and Cyttarocylis possess reticulated loricae which could be confused with the typically hexagonal infrastructure of Parafavella loricae. Neither Cyttarocylis or Xystonella have the well-defined oral denticles typically present in Parafavella.

Lindley (1975) also reported at least 13 specimens of an unidentified Cymatocylis species collected with the continuous plankton recorder. This device is possibly not as gentle a method of collection as whole water samples, and although tintinnids are more sturdy than aloricate ciliates, their loricae are much more fragile than thecate dinoflagellates and copepods which appear to be collected by the continuous plankton recorder with less distortion. Even the weight of a
Rampi (1948) reported Ptychocylis urnula from the Ligurian Sea near San Remo, Italy, but gave no other details except to note that it was rare. $P$. urnula is widespread in both the North Atlantic and North Pacific, but Rampi's is the only record for this genus in the Mediterranean despite 2 extensive surveys of Mediterranean tintinnids (Jörgensen 1924, Balech 1959) and several extensive annual studies (Margalef \& Morales 1960, Posta 1963, Travers \& Travers 1971. 


\section{Cricundella}

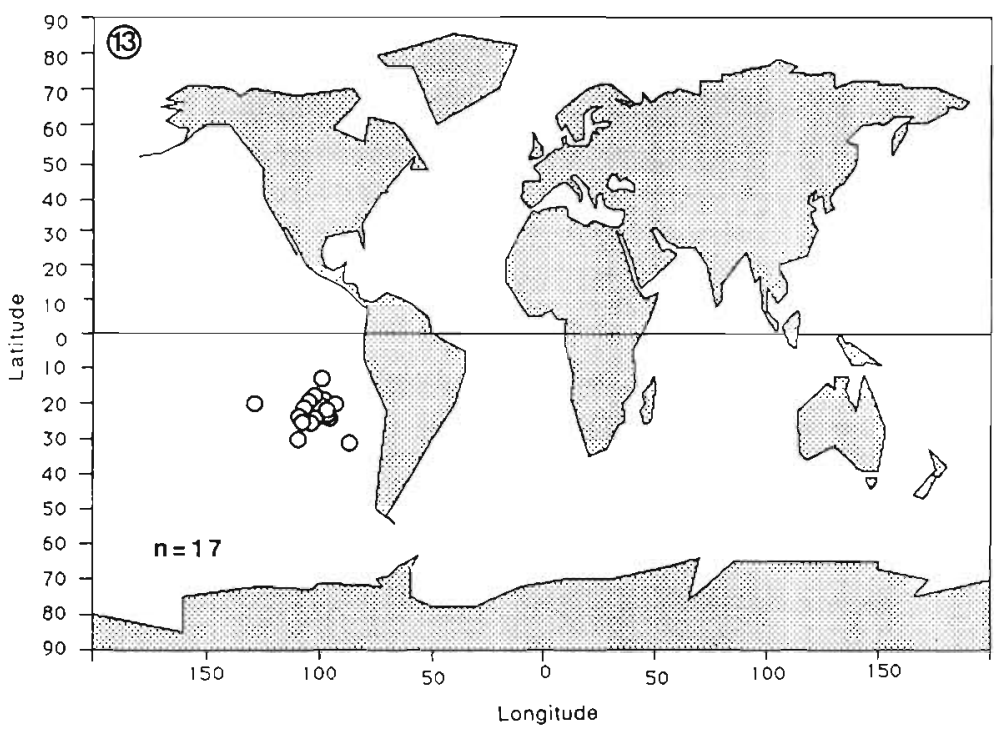

Fig. 13. Global distribution of the genus Cricundella

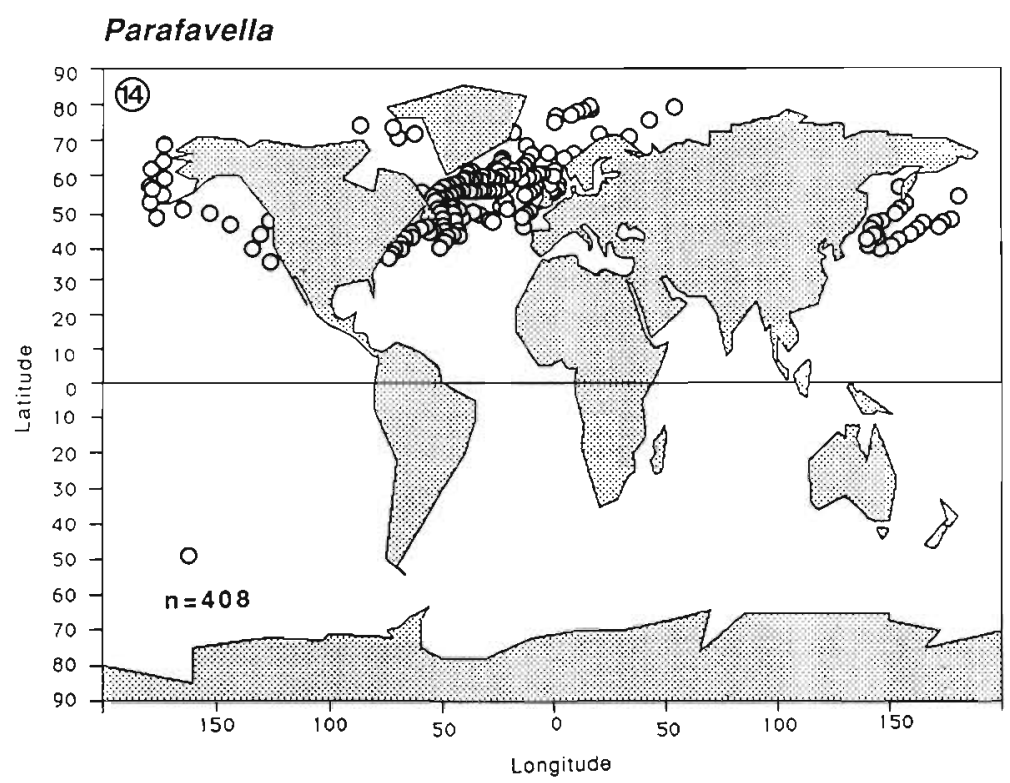

Fig. 14. Global distribution of the genus Parafavella

few specimens. Two of these species are also questionable members of the genus. Since no micrographs or drawings were given, it is impossible to confirm or deny that these reports are other than what the authors believed them to be. Assuming that it would be difficult for these cold water species to survive transport through the tropics, and these genera have been otherwise unreported in often thoroughly surveyed areas, it would not seem unreasonable to reassign these reports to the category of 'unidentified tintinnids', a category which usually accompanies any survey of these organisms.

Knowing the normal biogeographic ranges of certain tintinnid genera, workers who find what appear to be 'out of place' tintinnids would be alerted to the novelty of their find, and could take extra steps to document these range extensions. It would be important to note if loricae of such individuals were empty or damaged, thus suggesting long-distance transport. Conversely, if the loricae were occupied by the ciliate at the time of collection, it seems likely that it was either living where it was caught, or was not transported from a great distance.

\section{Bipolarity}

Acanthostomella norvegica (Fig. 18) is the only tintinnid we found to have a bipolar distribution. If real, this distribution is puzzling, since Smayda (1958) argued that bipolarity cannot exist in either the phytoplankton or the zooplankton, suggesting that organisms which appear to show bipolarity are actually cosmopolitan, existing at depth within the tropics. We discuss 4 possible explanations to explain the bipolar distribution of $A$. norvegica. (1) The species may exist at depth in the tropics but has not yet been discovered. This seems unlikely since, in terms of

Travers 1973, Rassoulzadegan 1979). Although it is possible that Rampi's record could be an indication of an intrusion of North Atlantic water into the Mediterranean Sea, the distance to the next closest report of Ptychocylis (Fig. 15) makes this seem unlikely.

It is interesting that these anomalous records are for genera known to have highly variable lorica morphology, and that these records were based upon very tintinnids, the North Atlantic has been one of the most thoroughly surveyed locations of the ocean, yet this species has been found only in the colder parts of this area. (2) Since the genus Acanthostomella is cosmopolitan (Kofoid \& Campbell 1939, Campbell 1942, Gaarder 1946, Balech 1971, Lindley 1975, Taniguchi 1977, Souto 1981), the species A. norvegica may be polymorphic and cosmopolitan, existing in the tropics as a 


\section{Ptychocylis}

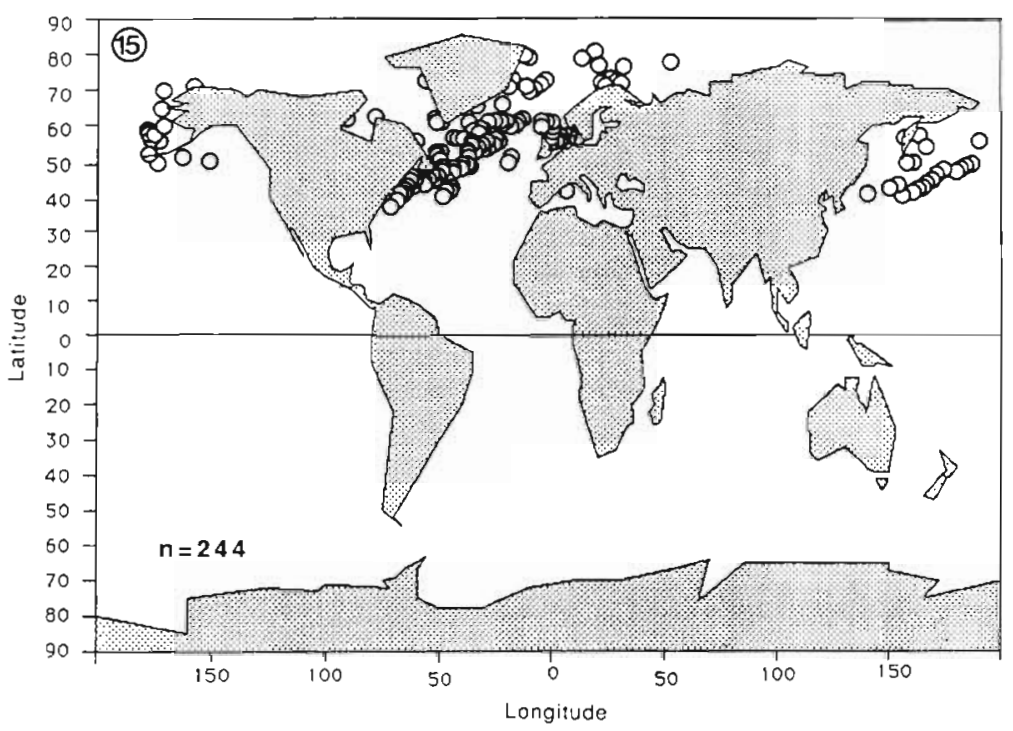

Fig. 15. Global distribution of the genus Ptychocylis

\section{Cymatocylis}

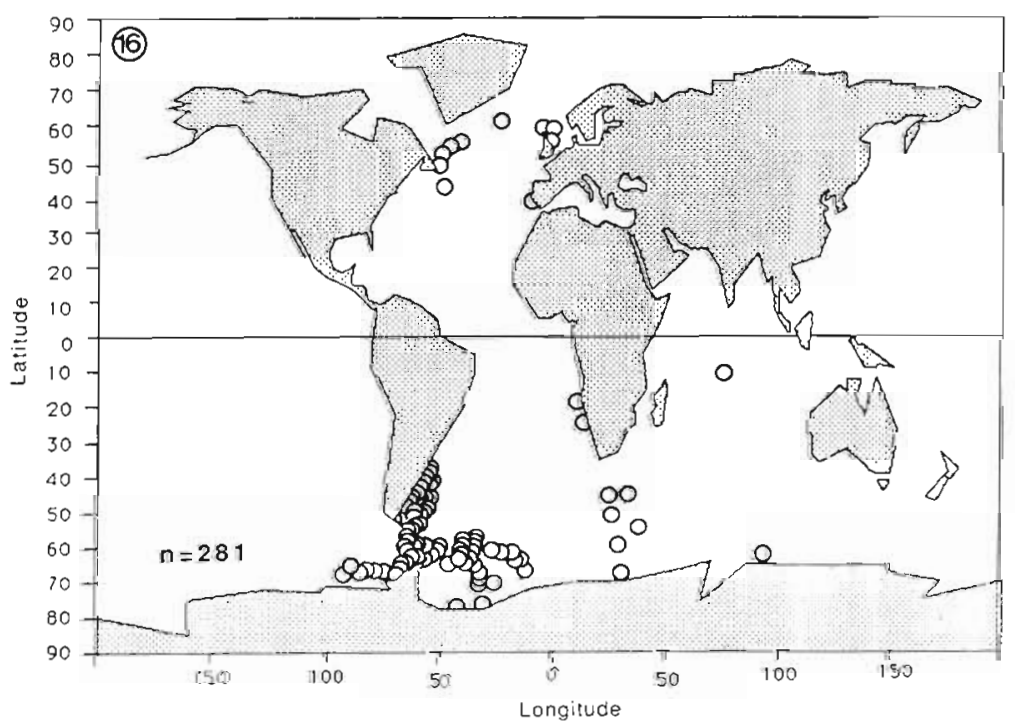

Fig. 16. Global distribution of the genus Cymatocylis

Oyashio, but that this species was not collected in the warm Kuroshio. No other member of this genus was present in the Kuroshio even though $A$. norvegica was very abundant in Oyashio waters. (3) The northern and southern populations of A. norvegica are possibly an example of convergent evolution within the genus. Unfortunately, we have no information to either support or refute this hypothesis, although the application of genetic techniques and protargol silver staining may give us some insight in the future. (4) A. norvegica may have had a continuous distribution in the past, perhaps during the ice ages, but when the tropics warmed the species' distribution contracted toward the poles.

Hypothesis (4) is what Pielou (1979) classified as an evolutionary disjunction. The most notable example of an evolutionary disjunction is demonstrated by the euphausid Thysanoessa gregaria, in which the northern and southern populations have not yet shown any apparent morphological or genetic divergences (Pielou 1979). Pielou also noted, however, that for this mechanism to work, the species involved must be restricted to the upper $200 \mathrm{~m}$ of the water column. Below this depth, water is relatively unaffected by atmospheric conditions, and organisms living there can travel more freely from pole to pole.

In one of the few studies on the vertical distribution of tintinnids, Kršinić (1982) found that over $90 \%$ of the tintinnid population in the open waters of the Adriatic Sea lived in the top $100 \mathrm{~m}$ of the water column. Those species commonly found at depths of greater than $100 \mathrm{~m}$ were rarely found at shallower depths. Acanthostomella norvegica is typically found in the surface waters in both parts of its range, and so this distribution may be the result of an evolutionary disjunc.

form morphologically different enough from its polar conspecific to be currently considered a different species. Temperature has been shown to cause differences in lorica formation in other species (Gold \& Morales 1974, 1975), but most of this variation is in lorica length. Lorica length is recognized as a highly variable character, and does not seem to be a major cause of taxonomic confusion in this case. Also, Taniguchi (1983) found that $A$. norvegica was a good indicator of the cold tion. Unfortunately, the fossil record for tintinnids is incomplete, so we may never be able to further examine this hypothesis. It is also doubtful that the tropics would be cool enough for this species even during periods of glaciation (CLIMAP Project Members 1976).

Smayda (1958) concluded that bipolar distributions are probably not due to the transport of diapausing cysts, and we agree in the case of Acanthostomella norvegica, even though this species is known to pro- 


\section{Laackmanniella}

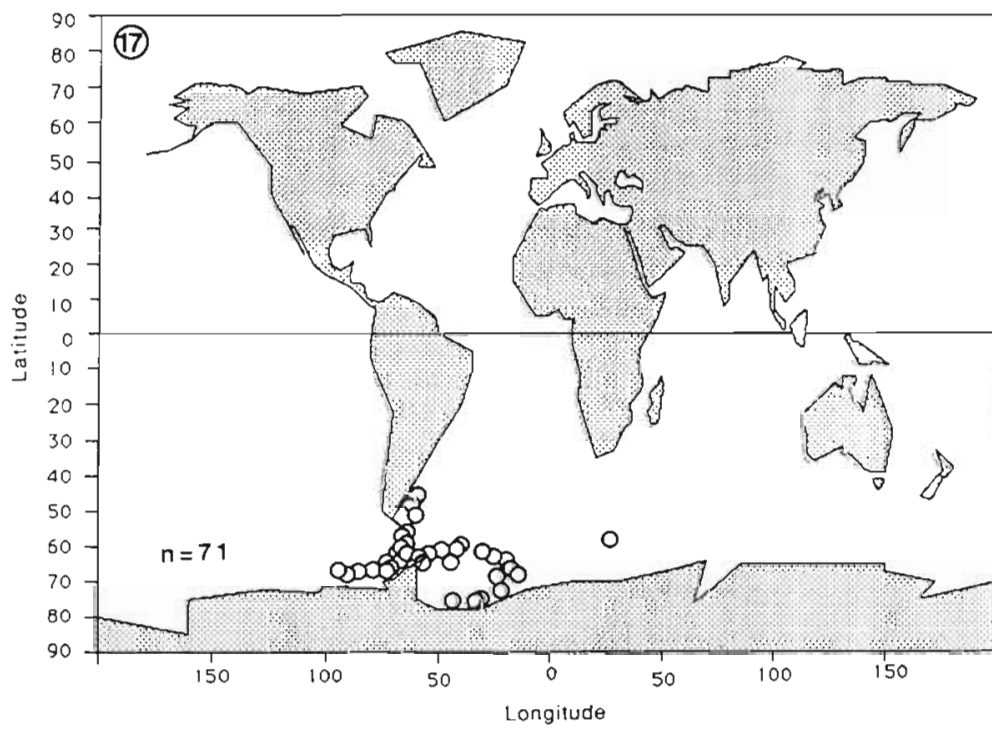

Fig. 17. Global distribution of the genus Laackmanniella

\section{Acanthostomella norvegica}

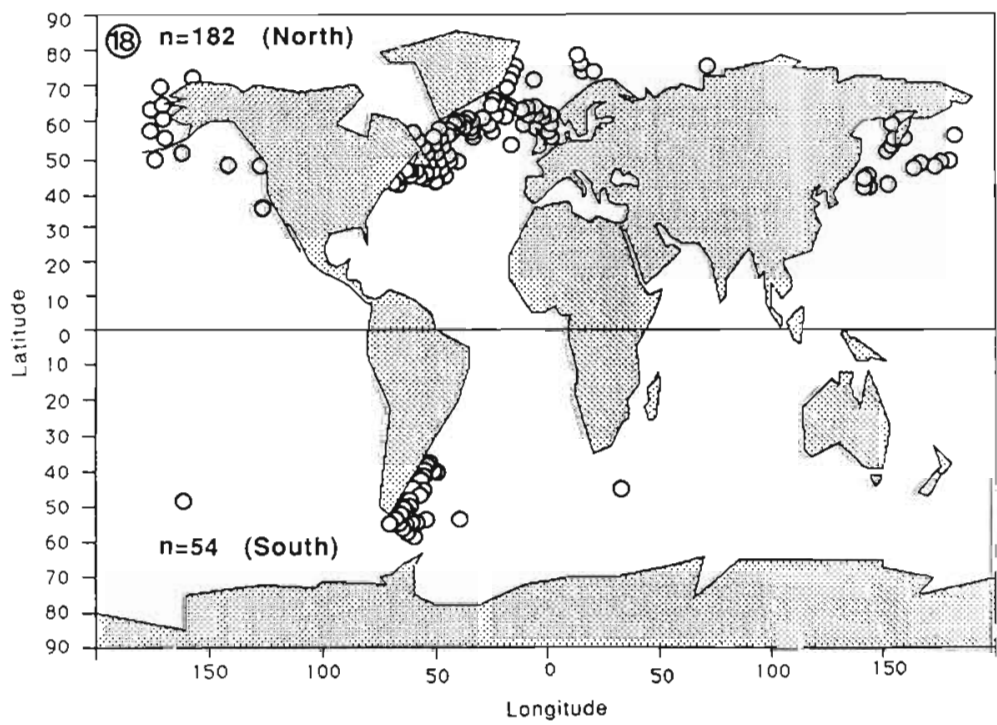

Fig. 18. Global distribution of the genus Acanthostomella norvegica duce resting cysts. Tintinnid cysts probably have high enough sinking rates to be deposited in the benthos under the planktonic range of a species, rendering transoceanic deep transport through the tropics unlikely.

\section{CONCLUSION}

Biogeography is the study of organisms and their distributions in space and time. These distributions are the end sum of all biotic and abiotic factors, and thus a knowledge of biogeography is highly relevant to ecological questions. This investigation shows that tintinnids are an appropriate topic for global biogeographic studies. Although identification at the species level is often problematic, genus may be useful. Laval-Peuto (1981, 1983), however, demonstrated that even genus-level identifications may be complicated in some instances by life-cycle events.

Many of the possible environmental factors limiting tintinnid distributions are discussed in this paper, but the relative importance of these factors to tintinnid distributions remains unclear. There are also many other questions which remain unanswered. For example, how does the presence of empty loricae in plankton samples affect our notions of tintinnid distributions? We do not know much about transport of empty loricae and how long empty loricae remain intact in the water column since sinking rates have only been calculated for a few species (Smayda \& Bienfang 1983). Thus, before we can answer the problems regarding tintinnid biogeography, especially their use as indicator organisms, many more questions need to be answered.

Appendix. Sources of biogeographic data

Abboud-Abi Saab, M. (1989). J. Plankton Res. 11: 203-222 Admiraal, W., Venekamp, L. A. H. (1986). Neth. J. Sea Res. 20 $61-66$

Alder, V. A., Boltovskoy, D. (1991a). Polar Biol. 11: 103-112

Alder, V. A., Boltovskoy, D. (1991b). Mar. Chem. 35: 337-346

Andersen, P., Serensen, H. M. (1986). Mar. Ecol. Prog. Ser. 33 99-109

Ayukai, T. (1987). Mar. microb. Food Webs 2: 45-52

Ayukai, T. (1991). J. Plankton Res. 13: 895-899
Bakker, C. Phaff, W J (1976) Hydrobiologia 50: 101-111

Balech, E. (1942). Physis, B. Aires 19: 242-252

Balech, E. (1944). Physis, B. Aires 19: 423-446

Balech, E. (1945). Physis, B. Aires 20:1-15

Balech, E. (1947). Physis, B. Aires, 20: 75-91

Balech, E. (1948). Comun. Mus. argent. Cienc. nat. Bernardino

Rivadavia Inst. nac. Invest. Cienc. Zool. 7: 1-23

Balech, E. (1958a). Vie Milieu 8: 382-408

Balech, E. (1958b). Physis, B. Aires, 21: 75-108 
Appendix (continued)

Balech, E. (1959a). Calif. coop. ocean. Fish. Invest. 1: 127-132

Balech, E. (1959b). Trab. Inst. esp. Oceanogr. 28: 1-88

Balech, E. (1962). Revta. Mus. argent. Cienc. nat. Bernardino Rivadavia Inst. nac. Invest. Cienc. Zool. 7: 3-249

Balech, E., El-Sayed, S. Z. (1965). In: Amer. Geophys. Union. Biology of the Antarclic Seas. Antarctic Research Series 5: 107-124

Balech, E. (1967). Bull. mar. Sci. 17: 280-298

Balech, E. (1968). Revta. Mus. argent. Cienc. nat. Bernardıno Rivadavia Inst. nac. Hidrobiologia 2: 165-197

Balech, E. (1971). Revta. Mus. argent. Cienc. nat. Bernardino Rivadavia Inst. nac. Hidrobiologia 3: 1-202

Balech, E. (1973). Contrnes Inst. antarct. argent. 107: 3-63

Balech, E. (1975). Physis, B. Aires, 34: 377-398

Balech, E., Souto, S. (1980). Physis, B. Aires, Secc. A 39: 1-8

Barria de Cao, M. S. (1986). Boln. Inst. esp. Oceanogr. 3: 143-150

Beers, J. R., Stewart, G. L. (1967). J. Fish. Res Bd Can. 24: 2053-2068

Beers, J. R., Stewart, G. L. (1969). J. Cons int. Explor. Mer 33: 30-44

Beers, J. R, Stewart, G. L. (1970). Bull. Scripps Inst. Oceanogr. (New Ser.) 17: 67-87

Beers, J. R., Stewart, G. L. (1971). Deep Sea Res. 18: 851-883

Beers, J. R., Stevenson, M. R., Eppley, R. W., Brooks, E. R. (1971). Fish. Bull. 69: 859-879

Beers, J. R., Reid, F. M. H., Stewart, G. L. (1975). Int. Revue ges. Hydrobiol. 60: 607 -638

Bigelow, H. B. (1928). Bull. U.S. Bur. Fish. 40: 1-509

Blackbourn, D. J. (1974). Ph.D. thesis, University of British Columbia, Vancouver, B.C.

Boikova, E. (1984). Ophelia, Suppl. 3: 23-32

Botiovskoy, D. Alder, V. A., Spinelli, F (1989). Polar Biol. 9: 447-456

Boltovskoy, D., Dinofrio, E. O., Alder, V. A. (1990). J. Plankton Res. 12: 403-413

Brownlee, D. C. (1977). M.S. thesis, University of Maryland

Brownlee, D. C., Jacobs, F. (1987). In: Majumdar, S. K., Hall, L. W. Jr, Austin, H. M. (eds.) Contaminant problems and management of living Chesapeake Bay resources. Penn. Acad. Sci., p. 217-269 Burkovskii, I. V. (1973). Zoologicheskii Zh. 52: 1277-1285

Burkovskii, I. V., Zamyshlyak, E. A., Poskryakova, N.P. (1974). Zoologicheskii Zh. 53: 1757-1766

Burkovskii, I. V. (1976). Zoologicheskii Zh. 55: 325-336

Burns, D. A. (1983). N.Z. J. mar. Freshwat. Res. 17: 387-406

Bursa, A. (1961). J. Fish. Res. Bd Can. 18: 51-83

Calderón-Aragón, L. D. C., López-Ochoterena, E. (1973). Revta Soc. mex. Hist. Nat. 34: 71-86

Campbell, A. S. (1926a). Univ. Calif. Publs Zool. 29: 237-239

Campbell, A. S. (1926b). Univ. Calif. Publs Zool 29: 179-236

Campbell, A. S. (1927). Univ. Calif. Publs Zool. 29: 429-452

Campbell, A. S. (1942). Publs Carnegie Instn 537: 1-163

Capriulo, G. M. (1982). Mar. Biol. 71: 73-86

Capriulo, G. M., Ninivaggi, D. V. (1982). Annls Inst. océanogr., Paris 58(S): 325-334

Capriulo, G. M., Carpenter, E. J. (1983). Mar. Ecol. Prog. Ser. 10: $277-288$

Capriulo, G. M., Taveras, J., Gold, K. (1986). Mar. Ecol. Prog. Ser. 30: $145-158$

Cardinal, A., Lafleur, P. E., Bonneau, E. (1977). Acta Protozool., Warsz 16: $15-22$

Chang, F. H. (1983). N.Z. J. mar. Freshwat. Res. 1.7: 279-304

Chang. F. H. (1990). N.Z. J. mar. Freshwat. Res. 24: 187-195

Chester, A. J. (1978). NOAA Tech. Rep. ERL 403-PMEL 30

Cleve, P. T. (1899). Ofvers. K. VetenskAkad. Forh. 56: 969-975

Cleve, P. T. (1900a). Goteborgs K. Vetensk.-0. VitterhSamh. Handl. 3: 3-369

Cleve, P. T. (1900b). Ofvers. K. VetenskAkad. Forh. 57: 919-938

Cleve, P. T (1902). Göteborgs K. Vetensk.-o. VitterhSamh. Handl. 4: 13-51

Coats, D. W., Heinbokel, J. F. (1982). Mar. Biol. 67: 71-79

Coats, D. W. (1988). J. Protozool. 35: 607-617

Coats, D. W. Heisler, J. J. (1989). Mar. Biol. 101: 401-409

Cortois, R., Dodson, J. J. (1986). Can. J. Fish. aquat. Sci. 43: 968-979

Cosper, T. C. (1972). Bull. mar. Sci. 22: 391-417

Dakin, W. J., Colefax, A. N. (1940). Publ. Univ. Sydney, Zool. Dept Monograph No. 1

Dale, T. (1987). Mar. microb. Food Webs, 2: 15-28
Dale, T., DahI, E. (1987). J. Plankton Res. 9: 871-879

Dale, T. (1988). Sarsia 73: 179-191

Dale, T. (1989). Arch. Protistenk. 137: 45-55

Davis, C. C. (1950). Q. J. Fla Acad. Sci. 12: 67-103

Davis, C. C. Williams, R. H. (1950). Ecology 31: 519-531

Davis, C. C. (1978). Can. J. Zool. 56: 1822-1827

Davis, C. C. (1981). J. Plankton Res. 3: 433-443

Davis, C. C. (1982). Int. Revue ges. Hydrobiol. 67: 713-747

Davis, C. C. (1985). Int. Revue ges. Hydrobiol. 70: 21-26

Davis, C. C. (1986). Int. Revue ges. Hydrobiol. 71: 11-47

Dohi, K. (1982). Bull. Plankt. Soc. Japan 29: 77-87

Dolan, J. R. (1991). Estuar coast. Shelf Sci. 33: 137-152

Dolan, J. R., Coats, D. W (1991). Mar, microb. Food Webs 5: 81-93

Durán, M. (1957). Investigacion pesq., Barcelona 8: 97-120

Durán, M. (1965). Trab. Inst. esp. Oceanogr. 32: 1-29

Faria, J. G. De, Cunha, A. M. Da (1917). Mems. Inst. Oswaldo Cruz 9: $68-93$

Fornshell, J. A. (1979). J. Protozool. 26: 270-272

Gaarder, K. R. (1946). Rep. scient. Res. 'Michael Sars' N. Atlant. deep Sea Exped. $19102: 1-37$

Gast, V. (1985). Mar. Ecol. Prog. Ser. 22: 107-120

Gilron, G. L., Lynn, D. H. (1989a). Mar. Biol. 103; 413-416

Gilron, G. L., Lynn, D. H. (1989b). Estuar. coast. Shelf Sci. 29: 1-10

Gilron, G. L., Lynn, D. H., Smith, I. P. (1990) Carib. J. Sci. 26: 152-162

Gilron, G. L., Lynn, D. H., Roff, J. C. (1991). Mar. microb. Food Webs 5: $95-113$

Gold, K. (1974). Biol. Bull. mar. biol. Lab., Woods Hole 147: 477

Gold, K., Morales, E. (1974). J. Protozool. 21: 442

Gold, K., Morales, E. (1975a). J. Protozool. 22: 520-528

Gold, K., Morales, E. (1975b). Trans. Am. microsc. Soc. 94: 142-145

Gold, K., Morales, E. (1975c). Biol. Bull. mar. biol. Lab., Woods Hole 149: 427

Gold, K., Morales, E. (1976). Biol. Bull. mar. biol. Lab., Woods Hole 150: $377-392$

Gold, K., Morales, E. (1977). J. Protozool 24: 580-587

Govoni, J. J., Hoss, D. E., Chester, A. J. (1983). Mar. Ecol. Prog. Ser. 13: $189-199$

Govoni, J. J., Chester, A. J. (1990). J. Plankton Res. 12: 819-830

Graziano, C. (1989). Estuar. coast. Shelf Sci. 29: 233-245

Hada, Y. (1932a). J. Fac. Sci. Hokkaido Univ. Ser. VI Zool. 2: 37-59

Hada, Y. (1932b). Proc. imp. Acad. Japan 8: 209-212

Hada, Y. (1932c). Scient. Rep. Tohoku imp. Univ., 4th Ser. Biol. 7 : $553-573$

Hada, Y. (1937). J. Fac. Sci. Hokkaido Univ., Ser. VI Zool. 5: 143-216

Hada, Y. (1970). JARE Sci. Rep., Ser. E 31: 1-51

Hada, Y (1972). In: Takenouti, A. Y. (ed.) Biological oceanography of the northern North Pacific Ocean. Idemitsu Shoten, Tokyo, p. $173-188$

Hansen, P. J. (1989). Mar. Ecol. Prog. Ser. 53: 105-116

Hara, S., Tanoue, E. (1985). Trans. Tokyo Univ. Fish. 6: 99-115

Hargraves, P. E. (1981). J. Plankton Res. 3: 81-91

Hattori, H., Yuki, K., Zaitsev, Y P., Motoda, S. (1983). Mer, Tokyo 21: $11-20$

Hedin, H. (1974). Zoon 2: 123-133

Hedin, H. (1975a). Zoon 3: 11-18

Hedin, H. (1975b). Zoon 3: 125-140

Hedin, H. (1976a). Zoon 4: 3-10

Hedin, H. (1976b). Acta zool., Stockh. 57: 113-118

Heimdal, B. R. Taasen, J. P., Elbrächter, M. (1977). Sarsia 63: 75-83

Heunbokel, J. F. (1977). Ph.D. dissertation. Univ. Calif, San Diego

Heinbokel, J. F. (1978a). Mar. Biol. 47: 177-189

Heinbokel, J. F. (1978b). Mar. Biol. 47: 191-197

Heinbakel, J. F., Beers, J. R. (1979). Mar. B1ol. 52: 23-32

Heinbokel, J. F., Coats, D. W. (1984). Antarct. J. 19: 111-113

Heinbokel, J. F., Coats, D. W. (1986). Mar. Ecol. Prog. Ser. 33: 71-80

Heinbokel J. F. (1987). Mar microb. Food Webs 2: 1-14

Heinbokel J. F. (1988). Mar. Ecol. Prog. Ser. 47: 239-248

Hermosilla, J. G. (1972). Boln Soc. Biol. Concepcion 44: 149-159

Hermosilla, J. G. (1973). Boln Soc. Biol. Concepcion 46: 11-36

Hermosilla, J. G. (1975). Gayana 34: 3-55

Hernroth, L. (1983). J. Plankt. Res. 5: 835-846

Hopkins, T L. (1966). Publs. Inst. mar. Sci. Univ. Tex. 11: 12-64 
Appendix (continued)

Jahn, A. E., Gadomski, D. M, Sowby, M. L. (1988). Fish. Bull. U.S 86: $251-262$

James, M. R. (1989). N.Z. J. mar. Freshwat. Res. 23: 507-518

Jenkins, G. P. (1987). J. expl. mar. Biol. Ecol. 110: 147-170

Jenkins, G. P. (1988). Mar. Ecol. Prog. Ser. 43: 233-244

Johansen, P. L. (1976). Ph.D. thesis. Dalhousie Univ., Halifax

Jörgensen, E. (1924). Rep. Dan. oceanogr. Exped. Mediterr. 2: 1-1 10

Kamiyama, T., Aizawa, Y (1987). Bull. Plankt. Soc. Japan 34: $185-191$

Kamiyama, T., Aizawa, Y. (1990). Bull. Plankt Soc. Japan 36: 137-139 Kawakami. R., Ayukai, T., Taniguchi، A. (1985). Bull. Plankt. Soc. Japan 32: 171-172

Kimor, B., Golandsky, B. (1977). Mar. Biol. 42: 55-67

Kimor, B., Golandsky-Baras, B. (1981). J. Plankton Res. 3: 445-459

Kofoid. C. A. (1905). Univ. Calif. Publs Zool. 1: 287-306

Kofoid, C. A., Campbell, A. S. (1929). Univ. Calif. Publs Zool. 34: 1-403

Kofoid, C. A., Campbell, A. S. (1939). Bull. Mus. comp. Zool. Harv. 84: $1-473$

Komarovsky, B. (1959). Bull. Sea Fish. Res. Stn Israel 21: 1-40

Komarovsky, B. (1962). Bull. Sea Fish. Res. Stn Israel 30:48-56

Konovalova, G. V., Rogachenko, L. A. (1974). Oceanology (a translation of Okeanologiia) 14:561-566

Krause, M., Kattner, G. (1989). J. Plankton Res. 11: 85-103

Krishnamurthy, K., Santhanam, R. (1978). Arch. Protistenk. 120(S): $138-141$

Krishnamurthy, K., Naidu, W. D., Santhanam, R. (1979). Arch. Protistenk. 122: 171-180

Kršinić, F. (1982). Mar. Biol. 68: 83-90

Krśinić, F. (1987a). Estuar. coast. Shelf Sci. 24: 401-408

Kršinić, F. (1987b). Estuar. coast. Shelf Sci. 24: 527-538

Kršinić, F. (1988). J. Plankton Res. 10: 413-429

Kruger, 1. (1980). Fish. Bull., S. Afr. 13: 31-53

Kuwahara, A., Kashiwai, M. Sinoda, M. (1975). J. oceanogr. Soc. Japan 31: 109-114

Laackmann, H. (1907). Zool. Anz. 31: 235-239

Laackmann, H. (1909). Dt. Südpol.-Exped. 11:340-496

Lackey, J. B., Balech, E. (1966). Trans. Am. microsc. Soc. 85: 575-578

Laval, M. (1972). Protistologica 8: 369-386

Laval-Peuto, M. (1975). Protistologica 11: 83-98

Laval-Peuto, M., Gold, K., Storm, E. R. (1979). Trans. Am. microsc. Soc. 98: 204-212

Laval-Peuto, M. (1981). Protistologica 17: 249-272

Laval-Peuto, M. (1983). Protistologica 29: 503-512

Leegaard, C. (1920). Acta Soc. Sci. fenn., Ser. B 48: 1-48

Leppanen, J.-M., Bruun, J.-E. (1988). Finn. mar. Res, 225: 55-78

Lindley, J. A. (1975). Bull. mar. Ecol. 8: 201-213

Ling, H. (1965). J. Paleont. 39: 721-723

Littlepage, J. L. (1968). Antarct. J. 3: 162-163

Lubel, M. A. A. (1974). Revta Soc. mex. Hist. Nat. 35: 45-76

Mamaeva, N. V. (1982). Sov. J. mar. Biol. (a translation of Biol. mor., Akad. Nauk SSSR) 8: 254-258

Mamaeva, N. V. (1984). Sov. J. mar. Biol. (a translation of Biol. mor., Akad. Nauk SSSR) 9: 180-185

Margalef, R., Morales, E. (1960). Investigación Pesq., Barcelona 16: 3-31

Margalef, R., Estrada, M. (1987). Investigación Pesq., Barcelona 51: $121-140$

Marrón-Aguilar, M. A., López-Ochoterena, E. (1969). Revta Soc. mex. Hist nat. 30: 43-64

Marshall, S. M. (1934). Scient. Rep. Gt Barrier Reef Exped. 4: 623-664

Masuti Alzamora, M. (1929). Notas Resum. Inst. esp. Oceanogr., serie II 32: 1-11

Masuti Alzamora, M. (1930). Notas Resum. Inst. esp. Oceanogr., serie II $43: 1-18$

Masuti Alzamora, M. (1933). Notas Resum. Inst. esp. Oceanogr. 2: 1-14

Middlebrook, K., Emerson, C. W., Roff, J. C., Lynn, D. H. (1987). Can. J. Zool. 65: 594-601

Murdoch, R. C. (1990). N.Z. J. mar. Freshwat. Res. 24: 519-527

Naidu, W. D. (1983). Mahasagar 16: 403-407

Naidu, W. D., Krishnamurthy, K. (1985). Mahasagar 18: 417-423

Nakashima, J., Kimoto, K. (1987). Bull. Seikai reg. Fish. Res. Lab. 64: $77-82$
Nakashima, J., Kimoto, K. (1989). Bull. Seikai reg. Fish. Res. Lab 67: 7-13

Okamura, K. (1907). Annotnes zool. japon. 6: 125-151

Ogilvie, H. S. (1927). Rept Fish. Bd Scotl. 1: 1-10

Ogilvie, H. S. (1938). Rapp. P.-v. Réun. Cons perm. int. Explor. Mer 107: 57-66

Osono-Tafall, B. F. (1941). Revta Soc. mex. Hist. Nat. 2: 147-173

Ostenfeld. C. H. (1901). Vidensk. Medder. dansk naturh. Foren. 1901: 128-133

Ostenfeld, C. H., Schmidt, J. (1901). Vidensk. Medder. dansk naturh. Foren. 1901: 141-182

Paranjape, M. A. (1980). J. exp. mar. Biol. Ecol 48: 23-33

Paranjape, M. A., Gold, K. (1982). Annls Inst. océanogr., Paris 58(S): $143-150$

Paranjape, M. A. (1987a). Can. J. Zool. 65: 41-48

Paranjape, M. A. (1987b). Mar. Ecol. Prog. Ser. 40: 239-246

Paranjape, M. A. (1990). Mar. Biol. 107: 321-328

Paredes, J. F. (1970). Mems Inst. Invest. cient. Moçamb. 10(Series A): $109-123$

Pierce, R. W. (1992). M.S. thesis, University of Massachusetts, Dartmouth

Posta, A. (1963). Cah. Biol. mar. 4: 201-210

Prasad, R. R. (1956). Indian J. Fish. 3: 1-42

Rampi, L. (1948a). Boll. Pesca Piscic Idrobiol 3: 50-56

Rampi, L. (1950). Bull. Inst. oceanogr., Monaco 965: 1-8

Rassoulzadegan, F. (1979). Investigácion pesq. 43: 417-448

Rassoulzadegan, F. (1980). Protistologica 26: 507-510

Rassoulzadegan, F., Etienne, M. (1981). Limnol. Oceanogr. 26: 258-270

Rassoulzadegan, F., Laval-Peuto, M., Sheldon, R. W. (1988). Hydrobiologia 159: 75-88

Revelante, N., Gilmartin, M. (1983). Oceanologica Acta 6: 407-415

Revelante, N., Gilmartin, M. (1987). Estuar. coast. Shelf Sci. 25: $581-598$

Revelante, N., Gilmartin, M. (1990). J. Plankton Res. 12: 89-107

Robertson, J. R. (1983). Estuar. coast. Shelf Sci.16: 27-36

Rogers, G. F., Roff, J. C., Lynn, D. H. (1981). Can. J. Zool 59. $2360-2364$

Round, F. E. (1967). J. exp. mar. Biol. Ecol. 1: 76-97

Roxas, H. A. (1941). Philipp. J. Sci. 74: 91-139

Sanders, R. W. (1987). J. Plankton Res. 9: 65-77

Sassi, R., Melo, G. D. N. (1986). Anais Acad. bras. Cienc. 58(S): 63-84

Sassi, R. Melo, G. N. (1989). Bolm Inst oceanogr. S. Paulo, 37: 59-74

Schmidt, J. (1901). Vidensk. Medder. dansk naturh. Foren. 1901: $183-190$

Silva, E. S. (1950). Bull. Inst. Oceanogr., Monaco 979: 1-28

Silva, E. S. (1953). Rev. Fac. Cienc. Lisboa, serie 2 2: 97-116

Smayda, T. J. (1958). Nytt Mag. Bot. 6: 75-96

Smetacek, V. (1981). Mar. Biol. 63: 1-11

Sniezek, J. H., Capriulo, G. M., Small, E. B., Russo, A. (1991). J. Protozool. 38: 589-594

Snyder, R. A., Brownlee, D. C. (1991). J. Protozool. 38: 583-589

Sorokin, V. 1. (1977). Mar. Biol. 41: 107-117

Souto, S. (1970a). Physis, B. Aires 30: 187-208

Souto, S. (1970b). Physis, B. Aures 30: 209-224

Souto, S. (1972). Physis, B. Aires 31: 451-462

Souto, S. (1974). Physis, B. Aires, Secc. B., Aguas Cont. Org. 33 201-205

Spittler, P. (1973). Oikos, suppl. 15: 128-132

Srinivasan, A., Santhanam, R., Jegatheesan, G. (1988). Indian J. mar. Sci. 17: 131-133

Stoecker, D. K., Guillard, R. R. L., Kavee, R. M. (1981). Biol. Bull mar. biol. Lab., Woods Hole 160: 136-145

Stoecker, D. K. Davis, L. H. Provan, A. (1983) Mar Biol 75: 293-302

Stoecker, D. K., Sanders, N. K. (1985). J. Plankton Res. 7: 85-100

Stoecker, D. K., Evans, G. T. (1985). Mar. Ecol. Prog. Ser. 25: 159-167

Suárez-Caabro, J. A., Gómez-Aguirre, S. (1965). Bull. mar. Sci. 15: $1072-1120$

Taguchi, S. (1976). Hydrobılologia 50: 195-204

Takahashi, M. Hoskins, K. D. (1978). J. exp. mar. Biol. Ecol. 32: 27-37

Takahashi, K., Ling, H. Y. (1984). Mar. Micropaleont. 9: 87-92

Taniguchi, A. (1977a). Bull. Plankt. Soc. Japan 24: 1-10

Taniguchi, A. (1977b). J. oceanogr. Soc. Japan 33: 82-89

Taniguchi, A., Hada, Y. (1981). Mer, Tokyo 19: 18-22 
Appendix (continued)

Taniguch1, A. (1983). Mer, Tokyo 21: 95-101

Taniguchi, A. (1984). Mem. natn. Inst. polar Res., Special Issue 32 : $63-76$

Taniguchi, A., Kawakami, R. (1983). Bull. Plankt. Soc. Japan 30: $33-40$

Taniguchı, A., Takeda, Y. (1988). Mar. microb. Food Webs 3: 21-34

Tiselius, P. T., Peterson, W. T. (1986). J. Plankton Res. 8: 183-195

Townsend, D. W. (1984). Mar. Ecol. Prog. Ser. 15: 79-90

Travers, A., Travers, M. (1971). Tethys 2: 639-646

Travers, M. (1973). Tethys 5: 31-53

Tumantseva, N. I. (1983). Oceanology (a translation of Okeanologiia) 23: 244-248

Tumantseva, N. I. (1989). Oceanology (a translation of Okeanologiia) 29: 96-99

Turner, J. T., Anderson, D. M. (1983). P.S.Z.N. I: Mar. Ecol. 4: $359-374$

Turner, J. T. (1984). Mar. Ecol. Prog. Ser. 15: 27-46

Umani, S. F., Honsell, G., Cabrini, M., Milani, L. (1985). Oebalia 11 (NS): $149-156$

Uribe, E., Castillo, J. (1982). Investnes mar., Valparaiso 10: 15-34
Verity, P. G. (1984). Ph.D. thesis, University of Rhode Island

Verity, P. G. (1986a). Mar. Ecol. Prog. Ser. 29: 105-115

Verity, P. G. (1986b). Mar. Ecol. Prog. Ser. 29: 117-126

Verity, P. G. (1987). Estuar. coast. Shelf Sci. 24: 671-690

Vitello, P. (1964). Pelagos 2: 5-41

Wailes, G.H. (1925). Br. Columbia Contr. Can. Biol. n.s. 2: 533-539

Wang, Ch. Ch., Nie, D. (1932). Contr biol. Lab. Sci. Soc. China Zool Ser. 8: 285-385

Wang, Ch. Ch. (1936). Sinensia, Shanghai 8: 353-370

Wasik, A., Mikolajczyk, E. (1990). Acta Protozool., Warsz. 29: 229-244

Watson, W., Davis, R. L. Jr (1989). Fish. Bull. U.S. 87: 569-591

Winter, A., Stockwell, D., Hargraves, P. E. (1986). Mar. Micropaleont. 10: 375-379

Yamamoto, T., Taniguchi, A., Nishizawa, S. (1981). Bull. Plankt. Soc. Japan 28: $111-120$

Yoo, K-I., Lee, J-B. (1987). Bull. Korean Fish. Soc. 20: 230-236

Zeitzschel, B. (1966). Veröff. Inst. Meeresforsch. Bremerh. 2: 293-300

Zettzschel, B. (1967). Helgol. wiss. Meeresunters. 15: 589-601

Zeitzschel, B. (1969). Forsch. Ergebn. 'Meteor' (Reihe D), 4: 47-101

Zeitzschel. B. (1982). Annls Inst. océanogr., Paris 58(S): 91-116

\section{LITERATURE CITED}

Alder, V. A., Boltovskoy, D. (1991a). Microplanktonic distributional patterns west of the Antarctic Peninsula, with special emphasis on the tintinnids. Polar Bol. 11: 103-i12

Alder, V A., Boltovskoy, D. (1991b). The ecology and biogeography of tintinnid ciliates in the Atlantic sector of the Southern Ocean. Mar. Chem. 35: 337-349

Bakker, C., Phaff, W. J. (1976). Tintinnida from coastal waters of the S.W. Netherlands. I. The genus Tintinnopsis Stein. Hydrobiologia 50: 101-111

Balech, E. (1958a). Dinoflagellés et tintinnides de la Terre Adélie, Secteur Français Antarctique. Vie Milieu 8: $382-408$

Balech, E. (1958b). Plancton de la Campaña Antártica Argentina 1954-1955. Physis B. Aires 21: 75-108

Balech, E. (1959). Tintinnoinea del Mediterraneo. Trab. Inst. esp. Oceanogr. 28: 1-88

Balech, E. (1962). Tintinnoinea y dinoflagellata del Pacifico segun material de las expediciones Norpac y Downwind del Instituto Scripps de Oceanografia. Rev. Mus. Argent. Cienc, nat Bernardino Rivadavia, Cienc. Zool. 7: 3-249

Balech, E. (1971). Microplancton de la campaña oceanografica. Productividad III. Rev. Mus. Argent. Cienc. nat. Bernardino Rivadavia, Hidrobiologia 3: 1-202

Balech, E. (1972). Los tintinnidos indicadores de afloramientos de aguas (Ciliata). Physis, Buenos Aires 31: 519-528

Balech, E. (1973). Segunda contribucion al conocimiento del plancton del Mar de Bellingshausen. Contrib. Inst. Antart. Argent. 107: 3-63

Balech, E. (1975). La familia Undellidae (Protozoa, Ciliophora, Tintinnina). Physis 34(89): 377-398

Boltovskoy, D., Alder, V A., Spinelli, F. (1989). Summer Weddell Sea microplankton: assemblage structure, distribution and abundance, with special emphasis on the Tintinnina. Polar Biol. 9:447-456

Boltovskoy, D., Dinofrio, E. O., Alder, V A. (1990). Intraspecific variability in Antarctic tintinnids: the Cymatocylis affinis / convallaria species group. J. Plankton Res. 12: 403-413

Brownlee, D. C. (1977). The significance of cytological characteristics as revealed by protargol silver-staining in evaluating the systematics of the suborder Tintinnina. M.S. thesis. Dept Zool., University of Maryland, College Park
Burkovski, I. V. (1973). Variability of Parafavella denticulata in the White Sea. Zool. Zh. 52: 1277-1285

Campbell, A. S. (1942). The oceanic Tintinnoinea of the plankton gathered during the last cruise of the Carnegie: scientific results of Cruise VII of the Carnegie during 1928-1929 under command of Captain J P. Ault. Biol. II: Carnegie Inst. Washington, Pub. 537, p. 1-163

Campbell, A. S. (1954). Tintinnina. In: Moore, R. C. (ed.) Treatise on invertebrate paleontology. D. Protista 3. Kansas Press, Lawrence, p. 166-180

Choi, J. K., Coats, D. W., Brownlee, D. C., Small, E. B. (1992). Morphology and infraciliature of three species of Eutintinnus (Ciliophora; Tintinnina) with guidelines for interpreting protargol-stained tintinnine ciliates. J. Protozool. 39: $80-92$

CLIMAP Project Members (1976). The surface of the ice-age Earth. Science 191: 1131-1137

Corliss, J. O. (1979). The ciliated Protozoa. Characterization, classification, and guide to the literature, 2nd edn. Pergamon Press, Oxford

Daday, E. von (1887). Monographie der Familie der Tintinnodeen. Mitt. zool. Stn. Neapel 7:473-591

Davis, C. C. (1978). Variations of the lorica in the Genus Parafavella (Protozoa: Tintinnida) in northern Norway waters. Can. J. Zool. 56: 1822-1827

Davis, C. C. (1981). Variations of lorica shape in the genus Ptychocylis in relation to species identification. J. Plankton Res. 3: 433-443

Echols, R. J., Fowler, G. A. (1973). Agglutinated tintinnid loricae from some Recent and Late Pleistocene shelf sediments. Micropaleontology 19: 431-443

Ekman, S. (1953). Zoogeography of the sea. Sidgwick \& Jackson, London

Frost, B. W. (1989). A taxonomy of the marine calanoid copepod genus Pseudocalanus. Can. J. Zool. 67: 525-551

Gaarder, K. R. (1.946). Tintinnoinea from the 'Michael Sars' North Atlantic deep sea expedition 1910. Rep. Scient. Res. 'Michael Sars' N. Atlantic deep Sea Exped. 1910 2: $1-37$

Gold, K., Morales, E. (1974). Effects of temperature on two strains of Tintinnopsis tubulosa. J. Protozool. 21: 442

Gold, K., Morales, E. (1975). Seasonal changes in lorica sizes and the species of Tintinnida in the New York Bight. J. Protozool. 22: 520-528 
Gold, K., Morales, E. (1976). Observations on the nature and significance of the particles used by Tintinnida during lorica-building. Trans. Am. Microsc. Soc. 95: 69-72

Gold, K., Morales, E. (1977). Studies on the Tintinnida of Enewetak Atoll. J. Protozool. 24:580-587

Hada, Y (1932). The Tintinnoinea from the Sea of Okhotsk and its neighborhood. J. Fac. Sci. Hokkaido Univ. Ser. VI Zool. 2: $37-59$

Haeckel, E. (1873). Uber einige neue pelagische Infusorien. Jenaisch. Zeitschr. f. Naturw. 7: 561-568

Jorgensen, E. (1924). Mediterranean Tintinnidae. Rep. Dan. oceanogr. Exped. Mediterr. 2: 1-110

Kamiyama, T., Aizawa, Y. (1990). Excystment of tintinnid ciliates from marine sediments. Bull. Plankton Soc. Japan 36: $137-139$

Kamiyama, T., Aizawa, Y. (1992). Effects of temperature and light on tintinnid excystment from marine sediments. Nippon Suisan Gakk. 58: 877-884

Kofoid, C. A. (1915). Notes on the Tintinnoinea. Univ. Calif. Publs Zool. 16: 63-69

Kofoid, C. A., Campbell, A. S. (1929). A conspectus of the marine and freshwater Ciliata belonging to the suborder Tintinnoinea, with descriptions of new species primarily from the Agassiz Expedition to the Eastern Tropical Pacific 1904-1905. Univ. Calif. Publs Zool. 34: 1-403

Kofoid, C. A., Campbell, A. S. (1939). Reports on the scientific results of the expedition to the Eastern Tropical Pacific, in charge of Alexander Agassiz, by U.S. Fish Commission Steamer 'Albatross', from October 1904 to March 1905, Lieut. Commander L. M. Garrett, U.S.N. commanding. 37 The Ciliata: the Tintinnoinea. Bull. Mus. Comp. Zool. Harvard Coll. 84: 1-473

Krishnamurthy, K., Naidu, W. D., Santhanam, R. (1979) Further studies on tintinnids (Protozoa: Ciliata). Arch. Protistenk. 122: 171-180

Kršinić, F. (1982). On vertical distribution of tintinnines (Ciliata, Oligotrichida, Tintinnina) in the open waters of the South Adriatic. Mar. Biol. 68: 83-90

Kršinić, F. (1987a). On the ecology of tintinnines in the Bay of Mali Ston (Eastern Adriatic). Estuar. coast. Shelf Sci. 24 $401-408$

Kršinić, F. (1987b). Tintinnids (Ciliophora, Oligotrichida, Tintinnina) in eastern Adriatic bays. Estuar. coast. Shelf Sci. 24: $527-538$

Kršinić, F. (1988). The family Xystonellidae (Ciliophora, Tintinnina) in the Adriatic Sea. J. Plankton Res. 10 $413-429$

Laackmann, H. (1907). Antarktische Tintinnen. Zool. Anz. 31: $235-239$

Laackmann, H. (1909). Die Tintinnideen der deutschen Südpolar Expedition 1901-1902. Dt. Südpol.-Exped. 11 $340-496$

Laval-Peuto, M. (1981). Construction of the lorica in Ciliata Tintinnina. In vivo study of Favella ehrenbergü: variability of the phenotypes during the cycle, biology, statistics, biometry. Protistologica 17: 249-272

Laval-Peuto, M. (1983). Sexual reproduction in Favella ehrenbergii (Ciliophora, Tintinnina). Taxonomical implications. Protistologica 29: 503-512

Laval-Peuto, M., Brownlee, D. C. (1986). Identification and systematics of the Tintinnina (Ciliophora): evaluation and suggestions for improvement. Annls Inst. acéanogr., Paris 62: $69-84$

Lindley, J. A. (1975). Continuous plankton records: a plankton atlas of the North Atlantic and North Sea: Supplement $3-$ Tintinnida (Protozoa, Ciliophora) in 1965. Bull. mar. Ecol. 8: $201-213$
Margalef, R., Morales, E. (1960). Fitoplancton de las costas de Blanes (Gerona) de Julio de 1956 a Junio de 1959 Investigación Pesq., Barcelona 16: 3-31

Naidu, W. D., Krishnamurthy, K. (1985). Biogeographical distribution of tintinnids (Protozoa: Ciliata) from Porto Novo waters. Mahasagar 18: 417-423

Paranjape, M. A., Gold, K. (1982). Cultivation of marine pelagic protozoa. Annls Inst. océanogr., Paris 58(S): $143-150$

Pielou, E. C. (1979). Biogeography. John Wiley \& Sons, New York

Pierce, R. W., Turner, J. T (1992). Ecology of planktonic ciliates in marine food webs. Rev. aquat. Sci. 6: 139-181

Posta, A. (1963). Relation entre l'évolution de quelques tintinnides de la rade de Villefranche et la témperature de l'eau. Cah. Biol. mar. 4: 201-210

Rampi, L. (1948). I tintinnoidi delle acque di San Remo. Boll. Pesca Piscic. Idrobiol. 3: 50-56

Rassoulzadegan, F. (1979). Évolution annuelle des ciliés pélagiques en Méditerraneé nord-occidentale. 2. Ciliés Oligotriches. Tintinnides (Tintinnina). Invest. Pesq. 43: $417-448$

Reid, P. C., John, A. W. G. (1978). Tintinnid cysts. J. mar. biol. Ass. U.K. 58: 551-557

Sevigny, J.-M., McLaren, J. A., Frost, B. W. (1989). Discrimination among and variation within species of Pseudocalanus based on the GPI locus. Mar. Biol. 102: 321-327

Shih, C.-T (1979). East-West diversity. In: van der Spoel, S., Pierrot-Bolts, A. C. (eds.) Zoogeography and diversity of plankton. John Wiley \& Sons, New York, p. 87-102

Shih, C.-T. (1986). Longitudinal distribution of oceanic calanoids (Crustacea: Copepoda): an example of marine biogeography. In: Schriever, G., Schminke, H. K., Shih, C.-T (eds.) Proceedings of the Second International Conference on Copepoda, Ottawa, Canada, 13-17 August 1984. Syllogeus No. 58. National Museums of Canada, p. $105-114$

Silva, E. S. (1953). Estudios de plancton na Lagoa de Obidos. II. Tintinnoinea. Rev. Fac. Cienc. Lisboa, serie 2, 2: 97-116

Smayda, T J. (1958). Biogeographical studies of marine phytoplankton. Oikos 9: 158-191

Smayda, T. J., Bienfang, P. K. (1983). Suspension properties of various phyletic groups of phytoplankton and tintinnids in an oligotrophic, subtropical system, P.S.Z.N. I.: Mar. Ecol. 4: $289-300$

Sniezek, J. H., Capriulo, G. M., Small, E. B., Russo, A. (1991). Nolaclusilis hudsonicus N.Sp. (Nolaclusiliidae N. Fam.) a bilaterally symmetrical tintinnine ciliate from the Lower Hudson River Estuary. J. Protozool. 38: 589-594

Snyder, R. A., Brownlee, D. C. (1991). Nolaclusilis bicornis N.G., N.Sp. (Tintinnina: Tintinnididae): a tintinnine ciliate with novel lorica and cell morphology from the Chesapeake Bay estuary. J. Protozool. 38: 583-589

Souto, S. (1981). Zooplancton del Atlantico Sudoccidental, Tintinnina. In: Boltovskoy, D. (ed.) Atlas del zooplancton del Atlantico sudoccidental y metodos de trabajo con el zooplancton marino. Instituto Nacional del Investigación y Desarrollo, Mar del Plata, Argentina, p. 353-381

Takahashi, K, Ling, H. Y. (1984). Particle selectivity of pelagic tintinnid agglutination. Mar. Micropaleont. 9: 87-92

Taniguchi, A. (1977). Biomass and size composition of copepod nauplii and tintinnids in the Philippine Sea and the Celebes Sea, summer 1972. Bull. Plankton Soc. Japan 24: $1-10$

Taniguchi, A. (1983). Microzooplankton distribution along a transverse section crossing a marked ocean front. Mer, Tokyo 21: 95-101 
Tappan, H., Loeblich, A. R. Jr (1973). Evolution of the oceanic plankton. Earth-Sci. Rev. 9: 207-240

Travers, A., Travers, M. (1971). Catalogue des tintinnides (Ciliés Oligotriches) récoltés dans le Golfe de Marseille de 1962 à 1964. Tethys 2: 639-646

Travers, M. (1973). Le microplancton du Golfe de Marseille variations de la composition systématique et de la densité des populations. Tethys 5: 31-53

Tumantseva, N. I. (1989). Role of mass species of infusoria in the composition of phytoplankton in Antarctic and Subantarctic waters of the Pacific Ocean. Oceanology (a translation of Okeanologiia) 29: 96-99

van der Spoel, S. (1986). Prepublication on variation in the lorica of Cymatocylis (Protozoa, Tintinnida, Ptychocylidae). Plank. Newsl. 4: 4-10

Wasik, A., Mikolajczyk, E. (1990). Tintinnids near pack-ice between South Shetland and the South Orkney Islands (26 Dec. 1988-18 Jan. 1989). Acta protozool., Warsz. 29:

This article was presented by R. Williams, Plymouth, UK
$229-244$

Yamamoto, T., Taniguchi, A., Nishizawa, S. (1981). Microplankton distribution at an oceanic front formed in the Sanriku waters off Northeast Japan. Bull. Plankt. Soc. Japan 28: 111-120

Zeitzschel, B. (1966). Die Verbreitung der Tintinnen im Nordatlantik. Veröff. Inst. Meeresforsch. Bremerh. 2: 293-300

Zeitzschel, B. (1967). Die Bedeutung der Tintinnen als Glied der Nahrungskette. Helgoländer wiss. Meeresunters. 15: $589-601$

Zeitzschel, B. (1969). Tintinnen des westlichen Arabischen Meeres, ihre Bedeutung als Indikatoren für Wasserkörper und Glied der Nahrungskette. Forsch. Ergebn. 'Meteor' (Reihe D) 4: 47-101

Zeitzschel, B. (1982). Zoogeography of pelagic marine protozoa. Annls Inst. océanogr., Paris 58(S): 91-116

Manuscript first received: April 8, 1992

Revised version accepted: January 6, 1993 